\title{
ZAŠTO JE VAŽNA BORBA PROTIV SMRTNE KAZNE?
}

Prof. dr. sc. Ivan Šimonović*

UDK: $343.25: 342.7 .01$

343.25:341.231.14

DOI: $10.3935 /$ zpfz.70.23.02

Izvorni znanstveni rad

Primljeno: lipanj 2020.

Premda je do relativno nedavno globalno kretanje u smjeru demokracije i ljudskih prava te napuštanja smrtne kazne izgledalo kao zavojita, ali jednosmjerna ulica, danas je očito da više nije tako. Premda brojke još ne upućuju na širenje smrtne kazne, jačanje autoritarnosti država i slabljenje ljudskih prava upućuju na oprez. Rezultati empirijskih istraživanja osnažuju tradicionalne argumente protiv smrtne kazne (nevino osudeni, arbitrarnost i diskriminacija u primjeni, protivnost ljudskim pravima), a oslabljuju argumente koji se najčěśce ističu njoj u prilog (odvraćajući učinci, pravda za žrtve). Također, upućuju i na neke nove argumente protiv smrtne kazne: negativni učinak na nevine tré́e osobe te povezanost između smrtne kazne i autoritarnosti. Borba protiv smrtne kazne važna je kao dio šireg mozaika zaštite ljudskih prava svakog pojedinca, ali i borbe za karakter društava u kojima će živjeti naše potomstvo.

Ključne riječi: smrtna kazna, ljudska prava, suverenost, autoritarnost, žrtve

\section{UVOD}

U 2019. godini evidentirano je 657 pogubljenja, sigurno najmanje u posljednjih deset godina, a vjerojatno ikad. ${ }^{1}$ Amnesty International registrirao

* Dr. sc. Ivan Šimonović, profesor Pravnog fakulteta Sveučilišta u Zagrebu, Trg Republike Hrvatske 14, 10000 Zagreb; veleposlanik, stalni predstavnik pri Stalnoj misiji Republike Hrvatske u Ujedinjenim narodima, 820 Second Avenue, 19th Fl., New York, N.Y. 10017, Sjedinjene Američke Države; ivan.simonovic@mvep.hr; ORCID ID: orcid.org/0000-0003-2209-8953

1 Vidi Amnesty International global report: Death sentences and executions 2019, Amnesty International 2020, str. 8. 
je pogubljenja u 20 zemalja, što je 11 manje nego prije dvadeset godina (31 u 1999.). Rezoluciju Opće skupštine UN-a o moratoriju na izvršenje smrtne kazne sa svrhom njezina postupnog ukidanja u prosincu 2018. podržala je 121 država, 35 je glasovalo protiv, a 32 su bile suzdržane ${ }^{2}$, što je najsnažnija podrška od 1994., otkad se podnose slične rezolucije. ${ }^{3}$

Gledajući povijesno i procjenjujući dugoročne trendove, broj smrtnih presuda i pogubljenja se, premda uz određene oscilacije, smanjuje već desetljećima. ${ }^{4} \mathrm{Na}$ kontinuumu između izvršavanja smrtne kazne, de facto moratorija na njezino izvršavanje, službenog proglašenja moratorija, abolicije smrtne kazne u miru i abolicije smrtne kazne u svim uvjetima, većina zemalja postupno se kreće u smjeru pune abolicije. Napredak u napuštanju smrtne kazne primjetan je $\mathrm{u}$ svim regijama svijeta. Danas je već više od dvije trećine država ukinulo smrtnu kaznu u pravnom sustavu ili praksi, a većina država - 106 - i formalno ju je ukinulo za sve zločine. ${ }^{5}$

Odnos međunarodnog prava, posebice međunarodnih ljudskih prava, spram smrtne kazne također evoluira. ${ }^{6}$ Premda se smrtna kazna uglavnom još smatra dopuštenom, međunarodni pravni okvir postupno se razvija u smjeru abolicije, zahtijevajući od država da ili ukinu smrtnu kaznu odmah ili da poduzmu

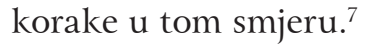

Je li uopće potrebno, ako su trendovi ionako usmjereni spram abolicije, a većina država ju je već i potpuno provela, ulagati neke dodatne napore u borbi protiv smrtne kazne?

2 General Assembly resolution 73/175, Moratorium on the use of the death penalty, A/RES/73/175 (17. prosinca 2018.).

3 Dapače, 1994. kada je Italija prvi put podnijela rezoluciju o moratoriju, izgubila je za osam glasova. S obzirom na to da se tekst rezolucije u kasnijim godinama više puta donekle mijenjao, rezultati nisu sasvim usporedivi. Ipak, trend rasta podrške bio je postojan sve do 2016., kada je došlo do stagnacije, odnosno malog zaostajanja. U lobiranju za podršku rezoluciji 2018. godine posebno je bila aktivna Europska unija, koja je borbu protiv smrtne kazne uvrstila među svoje vanjskopolitičke prioritete.

4 Vjerojatno i stoljećima, ali u ranijim razdobljima podaci nisu sustavno prikupljani.

5 Vidi Amnesty International global report: Death sentences and executions 2019, op. cit., str. 54.

6 Ovaj se razvoj ponajprije odvija kroz odgovarajuće tumačenje prava na život, odnosno na slobodu od mučenja i okrutnog, nečovječnog ili ponižavajućeg postupanja ili kazne.

7 Logika je slična kao kod zahtjeva za postupnim ostvarivanjem gospodarskih ili kulturnih prava. 
Smrtna je kazna jedno od "vječnih" pitanja u kojima se isprepliću pravo, politika, sociologija, psihologija i moralna filozofija na koje treba odgovoriti svaka generacija u svakom društvu.

U uvodu ću samo kratko naznačiti ključne argumente zbog čega smatram da je borba protiv smrtne kazne važna, a zatim ih u daljnjem tekstu dodatno razraditi. ${ }^{8}$

- Premda manji, broj pogubljenih i na smrt osudenih i dalje je visok.

o Nije riječ samo o stotinama registriranih pogubljenja, već i tisućama neregistriranih. Pretpostavlja se, naime, da su 2019. godine još tisuće pogubljene bez službenog traga. Neke države ne izvješćuju o pogubljenjima ${ }^{9}$, a druge broj pogubljenih i podatke o njima čak proglašavaju državnom tajnom. ${ }^{10}$

o Krajem 2019. čak 26.604 registriranih i još mnoge tisuće neregistriranih na smrt osuđenih sa strepnjom iščekuju svoju sudbinu.

o Broj abolicionističkih država, a još više ako uključimo i de facto abolicionističke države, jest velik, ali najmnogoljudnije države na svijetu poput Kine, Indije, SAD-a i Indonezije zadržavaju smrtnu kaznu, pa još gotovo polovica svjetske populacije živi pod prijetnjom smrtne kazne.

8 Kada se znanstveno raspravlja o temi koja je tako snažno vrijednosno obojena, metodološki je korektno eksplicirati svoje vrijednosti. Smrtnom kaznom se, na ovaj ili onaj način, bavim već više od 40 godina. Oduvijek sam bio abolicionist. Počevši od mojeg maturalnog rada na Klasičnoj gimnaziji u Zagrebu protiv smrtne kazne iz 1977. godine, zalagao sam se za njezino ukidanje u svim zemljama i u svim uvjetima. Danas sam jedan od povjerenika Međunarodnog povjerenstva protiv smrtne kazne (International Commission against the Death Penalty), koje se sastoji od male skupine uglavnom bivših nacionalnih ili UN-ovih dužnosnika koji su se tijekom karijere istaknuli u borbi protiv smrtne kazne. Uz pomoć država uključenih u Grupu za potporu (čiji je Hrvatska također član od 2020.), nastavljaju se zajednički boriti protiv smrtne kazne. Prirodno je stoga da sam i u ovom radu više prostora posvetio argumentima protiv, nego za smrtnu kaznu. U nastavku članka, često ću se pozivati na dvije abolicionistički orijentirane knjige u izdanju UN koje sam uredio u vrijeme kad sam bio pomoćnik glavnog tajnika UN za ljudska prava: Šimonović, I. (ur.), Moving Away from the Death Penalty: Arguments, Trends and Perspectives, United Nations, New York, 2015., https://read.un-ilibrary.org/human-rights-and-refugees/ moving-away-from-the-death-penalty_2bdca678-en, i Šimonović, I. (ur.), Death penalty and victims, United Nations, New York, 2016., https://www.ohchr.org/EN/ newyork/Documents/Death-Penalty-and-the-Victims-WEB.PDF.

9 Laos i Demokratska Republika Koreja.

Među države u kojima je broj pogubljenja tajna pripadaju Bjelorusija, Kina i Vijetnam. 
- Rezultati novijih istraživanja osnažuju argumente protiv, a dovode u pitanje argumente u prilog smrtne kazne. ${ }^{11}$

o Pravosudne pogreške ne samo da se događaju, nego se događaju češće nego što se to pretpostavljalo.

11 Među istraživanjima koja potvrđuju argumente protiv smrtne kazne, neka bih posebno izdvojio. O nevino osuđenima u SAD, vidi redovito ažurirane istraživačke podatke na web stranici Innocence Project (www. Innocenceproject.org), za istraživanje koje uključuje dubinsku analizu iste problematike vidi Gross, S. R.; O’Brien, B.; Hu, C.; Kennedy E. H., Rate of false conviction of criminal defendents who are sentenced to death, Proceedings of the National Academy of Sciences of the United States of America, sv. 111, br. 20, 20. svibnja 2014., str. 7230 - 7235, a za doprinos DNK analize u otkrivanju nevino osuđenih Garrett, B. L., Convincting the Innocent, Harvard University Press, Cambridge Massachusetts, London England, 2011. Za istraživanja fokusirana na diskriminatorni karakter smrtne kazne, posebice rasnu diskriminaciju, vidi Grosso, C. M.; O’Brien, B.; Taylor, A.; Woodworth, G., Race Discrimination and the Death Penalty: An Empirical and Legal Overview, u: Acker, J. R.; Lanier, C. S. (ur.), America's Experiment with Capital Punishment: Reflections on the Past, Present, and Future of the Ultimate Penal Sanction, treće izdanje, NC: Carolina Academic Press, Durham, 2014., str. 525 - 576 (u ovom je istraživanju posebni naglasak na diskriminaciji prilikom osuđivanja na smrtnu kaznu), te Phillips, S.; Marceau, J., Whom the State Kills, Phillips, Harvard Civil Rights - Civil Liberties Law Review, izlazi 2020, U Denver Legal Studies Research Paper br. 19-16, raspoloživo na: SSRN: https://ssrn.com/ abstract=3440828 ili http://dx.doi.org/10.2139/ssrn.3440828 (posebni naglasak je na odlučivanju o izvršavanju smrtne kazne). O kršenju ljudskih prava, posebice zabrane nečovječnog postupanja kao nužnoj popratnoj pojavi prigodom izvršavanja smrtne kazne, vidi Sarat, A., Gruesome Spectacles: Botched Executions and America's Death Penalty, Stanford University Press, Stanford, 2014. Također bih izdvojio neka istraživanja čiji rezultati dovode u pitanje argumente koji se tradicionalno navode u prilog smrtne kazne. Za nedostatak dokaza o odvraćajućim učincima, vidi najuvažavanije istraživanje provedeno za područje SAD, Deterrence and the Death Penalty, National Research Council of the National Academies, National Academic Press, Washington DC, 2012., a za vrlo metodološki zanimljivo komparativno istraživanje, u kojem su se kroz dulje razdoblje (tijekom kojeg se razlikovala praksa u pogledu primjene smrtne kazne) uspoređivala učestalost najtežih kaznenih djela u dva grada u Aziji, vidi Zimmering, F.; Fagan, D. J.; Johnson, T., Executions, deterrence and homicide: A tale of two cities, Journal of Empirical Legal Studies, sv. 7, br. 1, 2010., str. 1 - 29. O čestom izostanku satisfakcije koju smrtna kazna navodno donosi obiteljima žrtava, vidi Muller, R., Death Penalty May Not Bring Peace to Victims' Families, Psychology Today, October 19, 2016. i Radelet, M., The Incremental Retributive Impact of a Death Sentence Over Life Without Parole, University of Michigan Journal of Law Reform, sv. 49, br. 4, 2016. Za rezultate tematski različitih istraživanja širom svijeta koja osnažuju argumente protiv, a slabe argumente u prilog smrtne kazne, vidi Hoyle, C.; Hood, R., The Death Penalty: A Worldwide Perspective, peto izdanje, Oxford University Press, Oxford, 2015. 
o Ni nakon desetljeća sve sustavnijeg istraživanja nema dokaza da smrtna kazna odvraća od počinjenja najtežih kaznenih djela.

o Ima, međutim, dokaza da, gdje god postoji, posebno pogađa ranjive društvene skupine: manjine, migrante i gotovo bez iznimke siromašne. Činjenica da se smrtna kazna za ista kaznena djela, počinjena pod sličnim okolnostima, daleko češće izriče upravo pripadnicima ranjivih skupina, upućuje na njezin diskriminatorni karakter, narušavajući načelo jednakosti svih pred zakonom.

o Dvojbeno je donosi li smrtna kazna utjehu obiteljima žrtvi. Dio članova obitelji ne želi da se pogubljuje u njihovo ime, ali ima i ozbiljnih indicija da postojanje smrtne kazne negativno djeluje čak i na one članove obitelji koji žele pogubljenje.

- Rezultati istraživanja uz klasične upućuju i na neke nove argumente protiv smrtne kazne. $^{12}$

o Smrtna kazna daleko više nego ostale sankcije pogađa nevine treće osobe: članove obitelji osuđenih te sudionike u postupku njezina izricanja i izvršenja.

o Spomenuli smo da brojke govore o trendu napuštanja smrtne kazne, ali trend napuštanja smrtne kazne ne mora se nastaviti u budućnosti. Globalni kontekst koji je doprinosio napuštanju smrtne kazne se mijenja. Već godinama istraživanja govore o slabljenju demokracije i ljudskih prava. Strahovi koji proizlaze iz neuspješnog upravljanja globalizacijskim procesima pogoduju jačanju autoritarnih tendencija. U više država ponovno se zaziva povratak smrtnoj kazni. U svjetlu globalnog trenda jačanja autoritarnosti, korelacija između autoritarnosti države i sklonosti smrtnoj kazni, posebno je zabrinjavajuća.

Razloga za pojačane napore u bavljenju smrtnom kaznom, stoga, nažalost ima. U nastavku ću se detaljnije osvrnuti na relevantnost rezultata suvremenih istraživanja za klasične argumente protiv i za smrtnu kaznu te na nove argumente na koje upućuju. Također ću pokušati sugerirati i kako se najučinkovitije boriti protiv povratka smrtne kazne, odnosno za nastavak procesa njezina napuštanja.

12 O tome vidi Sharp, S. F., Hidden Victims: The Effects of the Death Penalty on Families of the Accused, Rutgers University Press, New Brunswick, 2005.; Gerber, R. J.; Johnson, J. M., The Top 10 Death Penalty Myths, Praeger, Westport, Connecticut, 2007. i Šimonović, I. (ur.), Death penalty and victims, United Nations, New York, 2016. 


\section{ARGUMENTI PROTIV SMRTNE KAZNE I ZA SMRTNU KAZNU}

Brojni rezultati provedenih istraživanja osnažuju klasične argumente za napuštanje smrtne kazne i dovode u pitanje osnovanost argumenata koji su se tradicionalno rabili u prilog smrtnoj kazni. Također, upućuju na relevantnost nekih novih argumenata za napuštanje smrtne kazne.

\subsection{Argumenti protiv}

Započet ćemo s klasičnim argumentima protiv smrtne kazne.

- Uvijek se sumnjalo da su katkad osuđeni na smrt, ili čak i pogubljeni, nevini. Rijetki slučajevi kada je to bilo i dokazano utjecali su u nekim državama na napuštanje smrtne kazne. No, stvarni postotak nevino osuđenih na smrt smatrao se ne samo nepoznatim, nego i nespoznatljivim. Uz to, neki sudionici u kaznenom progonu, posebice suci, ustrajavali su u mitu o svojoj nepogrešivosti. ${ }^{13}$

Sporadični slučajevi uspješnog dokazivanja nevinosti na smrt osuđenih upozoravali su da se događaju različite pogreške u pogledu policijskog postupanja, da svjedoci mogu griješiti, te da doušnici ili forenzički nalazi mogu biti nepouzdani.

Za to što sve tijekom postupka može poći krivo i kako predrasude utječu na osudu nevinih, dobro ilustrira slučaj Damiena Echolsa (o kojem je napisano više knjiga i snimljeno nekoliko filmova). ${ }^{14}$ Damien je uhićen kada je imao 18 godina, a nakon pravnog postupka koji je bio prepun pogrešaka proveo je isto toliko godina čekajući na izvršenje smrtne presude. Sam Damien navodi kako je slučaj protiv njega nalikovao bizarnom Frankensteinu, neprirodno skrpanom od nepovezanih dijelova. ${ }^{15}$

13 Tako je, primjerice, američki sudac Learned Hand "strah od duha nevino osuđenog" 1923. nazvao "nerealnim snom". No takva tvrdoglavost nije ostala zaboravljena u daljoj prošlosti: sudac Vrhovnog suda SAD-a Antonin Scalia još se prije dvadesetak godina pozivao da nevino osuđeni predstavljaju “zanemarivi minimum”, Kansas v. Marsh, 548 U.S. 163, 194-195 (2006.) (Scalia, J. concurring).

14 Damien Echols bio je gost na jednoj od niza tribina posvećenih napuštanju smrtne kazne koje sam u ime Ureda UN visoke povjerenice za ljudska prava vodio u UN-u u New Yorku između 2013. i 2016. godine.

15 Vidi Echols, D., The terrors of prison fade slowly, u: Šimonović, I. (ur.), Moving Away from the Death Penalty: Arguments, Trends and Perspectives, United Nations, New York, 2015., str. $103-106$. 
Damien i drugi mladić, Jason, osuđeni su u prvom redu na osnovi priznanja iznudenog pod prisilom od trećeg mladića s posebnim potrebama koji je, osim sebe, i njih dvojicu teretio za sotonistička, ritualna ubojstva dječaka. Uz to, zatvorski doušnik je svjedočio da mu je Jason priznao ubojstva dok su dijelili ćeliju. ${ }^{16} U$ dva odvojena postupka Damien je dobio smrtnu kaznu, a Jason $i$ treći mladić doživotnu robiju.

Dokazi protiv Damiena bili su, primjerice, da je čitao romane Stephena Kinga, slušao Iron Maiden i oblačio se u crno te da je pisao pjesme mračnog sadržaja. Ekspert je ocijenio da sve to upućuje na okultizam kao i činjenice da je ubojstvo izvršeno u noći punog mjeseca te da su ubijene tri žrtve jer je 666 vražji broj, a podijeljen s dva daje 333. Forenzičar je pak potvrdio da je nož, nađen odbačen u blizini, bilo oružje kojem su djeci nanesene ozljede. Svi osudeni bili su vrlo siromašni i tek kad je dokumentarni film sa suđenja pobudio pažnju novinara i istraživača te doprinio da se skupi novac za kvalitetnu obranu, počele su se otkrivati strašne greške. "Stručnjak za okultizam” završio je poslijediplomski $i$ doktorski dopisni tečaj na krajnje sumnjivoj instituciji (koju je država Kalifornija nakon suđenja zatvorila). Vodeći forenzičari utvrdili su da ozljede na tijelima žrtvi ne potječu od noža, kako je to ustvrdio prvotni forenzičar (koji je dva puta pao državni forenzički ispit), već su nakon smrti nanesene od strane životinja. Doušnik je kasnije priznao da je u ono vrijeme bio teški ovisnik o drogama, miješao stvarnost i maštu te da ne zna je li mu Jason dok je s njim dijelio ćeliju ikada priznao ubojstva kako je svjedočio tijekom postupka.

Ali, tek su mogućnost analize DNK-a, koja je postala dostupna u SAD-u krajem osamdesetih, a zatim i aktivistički pravni pokreti za dokazivanje

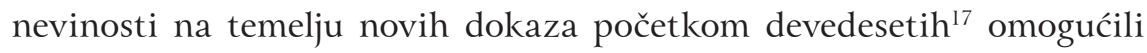
bolji uvid u stvarne razmjere osuda nevinih na smrt. Prvi nevino osuđeni na smrt, a zatim oslobođen na temelju analize DNK-a bio je Kirk Noble Bloodsworth 1993. godine. Dvadeset trogodišnji bivši marinac osuđen je za silovanje i ubojstvo djevojčice na temelju lažne dojave i pogrešne identifikacije od strane više svjedoka. Oslobođen je samo zahvaljujući tome što je prvostupanjski sudac, premda su službeno trebali biti uništeni,

16 O pogreškama u postupku detaljnije vidi Braga, S., Damien Echols and the West Memphis three case: a search for a motive run amok, u: Šimonović, ibid., str. 107 - 114.

17 Odvjetnici Barry Scheck i Peter Neufeld pionirski su 1990. na pravnom fakultetu Cardozo pokrenuli Projekt nevinost (Innocence Project). Za detaljniji uvid u problematiku nevino osuđenih u SAD-u vidi Garrett, op. cit. u bilj. 11.

Projekt nevinost je u razdoblju od 1989. do rujna 2019. dokumentirao 365 slučajeva ukidanja kazni nevino osuđenih na temelju analize DNK-a, od toga 130 smrtnih kazni (The New York Times, 11. prosinca 2019., str. A26). 
ipak sačuvao uzorke forenzičkog materijala koji su mogli biti podvrgnuti naknadnoj analizi. ${ }^{18}$ Nakon Kirka u SAD-u je još najmanje 129 na smrt osuđenih oslobođeno na temelju rezultata analize DNK-a. Od toga su neki, kao i Kirk, čak i na ponovljenim suđenjima znali biti iznova osuđeni na smrt, sve dok ih nisu spasili rezultati analize.

U SAD-u, gdje su se genetska testiranja prva počela sustavno provoditi, procjena "tamne brojke" nevino osuđenih na smrt, zasnovana na utvrđenim slučajevima pogrešnih osuda te uporabi sofisticiranih matematičkih modela ${ }^{19}$, penje se na najmanje 4,1 posto. ${ }^{20}$ Možemo samo pretpostavljati kakva je ona u državama u kojima je pravosudni sustav slabije razvijen i gdje se za vođenje slučajeva u kojima se može izreći smrtna kazna izdvaja osjetno manje sredstava. ${ }^{21}$ Uzimajući u obzir nesavršenosti svakog kaznenopravnog sustava, nepovratni učinak smrtne kazne jednostavno je neprihvatljiv rizik.

- Snažan učinak na protivljenje, a u nekim situacijama i napuštanje smrtne kazne imala su istraživanja o arbitrarnom karakteru i diskriminatornoj primjeni smrtne kazne. Ako smrtna kazna nije propisana kao jedina moguća za određeno djelo (što onda onemogućuje da se kazna prilagodi okolnostima slučaja i kosi se s međunarodno zajamčenim ljudskim pravima), otvara se pitanje kriterija prema kojima će ona biti izrečena nekim počiniteljima istog kaznenog djela, a nekima neće. U slučaju da ne postoje legitimni kriteriji te njihova konzistentna primjena, riječ je u najmanju ruku o arbitrarnosti u primjeni smrtne kazne, a ako su njome posebno pogođene neke društvene skupine, potencijalno i o njihovoj diskriminaciji.

Bivši tužitelj okruga Los Angeles u SAD-u navodi da ga je uvijek mučilo da se vjerojatnost izricanja smrtne kazne jako razlikovala u različitim pod-

18 Kirk Noble Bloodsworth također je bio moj gost na više tribina o smrtnoj kazni održanih u UN-u u New Yorku. O njegovu iskustvu vidi Bloodsworth, K., Without DNA evidence I'd still be behind bars, u: Śimonović, op. cit. u bilj. 15.

19 Model koji je nakon odgovarajuće prilagodbe poslužio za izračun posuđen je iz medicine, gdje je razvijen za procjenu vjerojatnosti preživljavanja u slučaju oboljenja.

20 Vidi Gross et al., op. cit. u bilj. 11, str. 7230 - 7235. Autori navode kako je riječ o vrlo konzervativnoj procjeni.

${ }^{21}$ Između 2004. i 2014. utvrđeni su slučajevi pogrešnih presuda na smrt u više država, uključujući Belize, Kinu, Japan, Malavi, Maleziju, Pakistan, Papuu Novu Gvineju, Filipine i Trinidad i Tobago; vidi Hoyle, C., Victims of wrongful conviction in retentionist nations, u: Šimonović, op. cit. u bilj. 12, str. 96. 
ručjima unutar okruga za koji je bio nadležan. ${ }^{22}$ Isto se moglo primijetiti i u cijeloj državi Kaliforniji: zašto bi neki imali koristi ili štete jer im se sudi u jednom okrugu, a ne u drugom? No, osim arbitrarnosti upozorio je i na diskriminaciju. Podaci za SAD za 2011. godinu pokazuju da je počiniteljima čija je žrtva bila bijela tri puta češće bila dosuđena smrtna kazna nego ako je žrtva bila crna. Premda su u Kaliforniji samo 27,6 \% žrtava ubojstva bile bijele, 80 \% pogubljenih su osuđeni za ubojstva bijelaca. ${ }^{23}$ I druga istraživanja u različitim razdobljima i različitim državama SAD-a upućuju na visok stupanj diskriminacije.

Uvid u praksu izricanja smrtne kazne širom svijeta također upućuje na to da se ona izriče i izvršava arbitrarno i diskriminatorno. ${ }^{24} \mathrm{U}$ pravilu, smrtnom su kaznom neproporcionalno često pogođeni pripadnici društveno posebno ranjivih skupina: pripadnici raznih manjina (rasnih, nacionalnih, vjerskih, etničkih, spolnih), migranti i, gotovo bez iznimke, siromašni. Osobe s mentalnim poremećajima ili mentalnim nedostatnostima, koje ne razumiju jezik te koje su bez financijskih mogućnosti za kvalitetnu obranu, lakše je prisiliti na lažna priznanja ili im ne omogućiti nepristrani sudski postupak te izvođenje svih za njih povoljnih dokaza i vještačenja. Dokazi o arbitrarnoj i diskriminatornoj primjeni znali su u nekim državama doprinijeti i da se smrtna kazna, odnosno njezina diskriminatorna primjena, proglasi protuustavnom. ${ }^{25}$

$\mathrm{S}$ motrišta morala, diskriminacija marginaliziranih i ranjivih društvenih skupina potpuno je neprihvatljiva. Upravo suprotno, ako ih se već razlikuje od većine, onda bi se upravo kod pripadnika takvih ranjivih skupina lakše

22 Gil Garcetti bio je tužitelj okruga Los Angeles od 1992. do 2000. (ukupno je 32 godine radio za ured tužitelja). Po broju stanovnika taj je okrug brojniji nego 43 države članice SAD-a. Vidi Garcetti, G., In the United States, growing doubts about the death penalty, u: Šimonović, op. cit. u bilj. 12, str. 39 - 40.

Ibid., str. 44.

Vidi u Šimonović, op. cit. u bilj. 15, Bulkan, A., The Death Penalty in the Commonwealth Carribean: Justice out of reach?, str. 130 - 149, Ramanthan, U., The death penalty in India: Down a slippery slope, str. 150 - 169 i Mogwe, A., The death penalty in Botswana: Barriers to equal justice, str. 170 - 179.

Tako, primjerice, Vrhovni sud SAD-a 1972. godine presudom u slučaju Furman v. Georgia, 408 US 238 (Supreme Court 1972) nije proglasio smrtnu kaznu protuustavnom, ali je proglasio protuustavnim zakone koji su je regulirali zbog rasne diskriminacije u njihovoj primjeni. No, ni kasniji od Vrhovnog suda prihvaćeni zakoni nakon presude u slučaju Gregg v. Georgia, 428 US 153 (Supreme Court 1976), koji su kroz zahtjev za bolji uvid u olakotne i otegotne okolnosti nastojali objektivizirati njezinu primjenu, nisu otklonili diskriminatornu primjenu smrtne kazne. 
mogle naći olakotne okolnosti vezane uz težak život, nedostatak prilika, siromaštvo, neobrazovanost ili ograničene intelektualne sposobnosti. ${ }^{26}$ Ovaj nesklad navodi neke autore na zaključak da se putem strukturne diskriminacije u provođenju kaznene politike, što se dobro vidi na primjeru smrtne kazne, prikriveno štite i promiču interesi vodećih, nauštrb prava i interesa diskriminiranih društvenih skupina. ${ }^{27}$

- Razvoj ljudskih prava sustavno sužava dopustivost smrtne kazne. Sužava se krug osoba kojima se može izreći, odnosno nad kojima se može izvršiti smrtna kazna, smanjuje se broj djela za koja je dopustiva te se uvode postupovne garancije u pogledu njezina izricanja i izvršenja. Dodatno, kroz radikalnu interpretaciju prava na život dovodi se u pitanje i legitimnost smrtne kazne uopće. Istodobno, kroz tumačenje zabrane mučenja te nehumanog i ponižavajućeg postupanja otežava se njezino izvršavanje gotovo do nemogućnosti. U ovom razvoju važnu ulogu osim nacionalnih tijela imaju i međunarodne institucije, na globalnoj razini posebice UN-ov Odbor za ljudska prava te razna regionalna tijela.

Članak 3. UN-ove Opće deklaracije o ljudskim pravima iz 1948. jamči svakome pravo na život. Ovo je pravo kasnije razrađeno u članku 6. Međunarodnog pakta o građanskim i političkim pravima iz 1966. (stupio na snagu 1976.) te kroz njegovo tumačenje od strane za to nadležnog UN-ova Odbora za ljudska prava. Člankom je dopuštena smrtna kazna kao iznimka, i to samo uz striktna ograničenja: da se život ne oduzima arbitrarno, da je izricanju smrtne kazne prethodio rigorozni postupak, da je ograničena samo za najteže zločine ${ }^{28}$, da se može izreći samo osobama koje su u vrijeme izvršenja djela bile punoljetne te da ne može biti izvršena nad trudnom ženom. Odredba da se ne može pozivati ni na što sadržano u članku da se spriječi aboliciju smrtne kazne u nekoj od stranaka Pakta upućuje da se abolicija smatra poželjnim ciljem.

26 Vidi opširnije Šimonović, I., Introduction - An Abolitionist's Perspective, u: Šimonović, op. cit. u bilj. 15, str. $14-15$.

27 Tako, primjerice, na temelju razmatranja odnosa između linča i smrtne kazne Kleinstuber zaključuje kako je smrtna kazna u SAD-u više oblik rasne nego društvene kontrole. Vidi Kleinstuber R., Discrimination and the death penalty, u: Šimonović, op. cit. u bilj. 12, str. 127.

28 Odbor za ljudska prava tumači zahtjeve u pogledu postupka na način da se traži poštovanje i drugih zahtjeva za pošteni pravni postupak sadržanih u čl. 14. Pakta te da njihovo kršenje prigodom odlučivanja o smrtnoj kazni predstavlja i kršenje prava na život. Također, najteže zločine tumači vrlo restriktivno, i to tako da djelo za koje se smrtna kazna može izreći mora uključivati ubojstvo s namjerom. 
Zamisao ove odredbe ojačana je Rezolucijom Opće skupštine UN-a 2857 (XXVI) iz 1971. godine, koja u svrhu zaštite prava na život traži ograničavanje djela za koja se smrtna kazna može izreći te kasnijim nizom rezolucija kojima se od država traži moratorij na izvršavanje smrtne kazne s konačnim ciljem njezina ukidanja. Tijekom godina ove su rezolucije dobivale sve snažniju potporu. Takav razvoj neke autore navodi na zaključak da se kvalitativno promijenio odnos spram smrtne kazne: dok je prije smrtna kazna bila norma, sad je to abolicija. Teret dokaza da opravdaju svoju poziciju stoga bi u današnje vrijeme trebao prijeći na one države koje zadržavaju smrtnu kaznu. ${ }^{29}$

Taj je teret još teži ako se treba dokazati i da smrtna kazna nije mučenje, ili da barem nije okrutna, nehumana i ponižavajuća, što je zabranjeno člankom 7. Međunarodnog pakta o građanskim i političkim pravima. Nijedan od načina izvršenja smrtne kazne koji se primjenjuju ne može se, naime, smatrati "humanim", čak ni kada prigodom izvršenja sve protekne uredno. K tome, kod svakog načina izvršenja povremeno nešto pođe krivo i osoba nad kojom se izvršava kazna podvrgnuta je prije smrti užasnim mukama.

Već i samo čekanje na izvršenje smrtne kazne nehumano je, okrutno i ponižavajuće. Uvjete u kojima se čeka izvršenje jedan je od osuđenika nazvao "loncem pod pritiskom za ljude".

Ako se tome doda da smrtna kazna često vrijeđa i druga ljudska prava, primjerice jednakost zbog arbitrarnosti u svojem izricanju i izvršavanju, zabranu diskriminacije jer su njome posebno pogođene ranjive društvene skupine, pa eventualno i prava djece čiji su roditelji osuđeni na smrt, jasno je da je smrtna kazna nespojiva s današnjim pragom postavljenim za zaštitu različitih ljudskih prava.

\subsection{Argumenti za}

Glavni argumenti pobornika zadržavanja smrtne kazne najčešće su odvraćanje od počinjenja najtežih kaznenih djela, i ostvarenje pravde, posebice pravde za žrtve. ${ }^{30}$

29 Vidi Heynes, C.; Probert, T., The right to life and the progressive abolition of the death penalty, u: Šimonović, op. cit. u bilj. 15, str. 218.

30 Odvraćanje i pravda shvaćena kao retribucija glavni su argumenti vlada mnogih država koje podržavaju smrtnu kaznu, tako primjerice Kine, Japana, Indonezije, Singapura i mnogih država Bliskog istoka i Afrike (vidi Hoyle, C.; Hood, R., Deterrence and public opinion, $\mathrm{u}$ : Šimonović, op. cit. u bilj. 15, str. 70. 
Rezultati istraživanja upućuju na to da su oba navedena argumenta na staklenim nogama. Započnimo s prvim, utilitaristički obojenim i na budućnost usmjerenim: odvraćanjem odnosno prevencijom.

- O odvraćajućim učincima smrtne kazne, odnosno njihovu izostanku, napisano je mnogo članaka i knjiga. Za odvraćajući učinak bilo koje kazne ključno je da se radi o prijetnji koja je dovoljno vjerodostojna da utječe na izbor ponašanja. Smrtna kazna ima snažnije odvraćajuće učinke ako uspješnije nego bilo koja druga kazna odvraća od počinjenja djela za koje je zapriječena. Potencijalni počinitelj odustaje od počinjenja djela upravo uslijed straha od smrtne, a ne neke druge kazne kao moguće posljedice. Kako nije moguć izravni eksperiment na individualnom planu, hoće li konkretna osoba počiniti neko kazneno djelo ili ne, ovisno o tome je li za njega zapriječena smrtna ili neka druga kazna ${ }^{31}$, najveću spoznajnu vrijednost imaju istraživanja na društvenom planu, u kojima se na odnos između postojanja smrtne kazne i rizika počinjenja najtežih kaznenih djela primjenjuju statističke i ekonometrijske tehnike. Usporedba razdoblja sa smrtnom kaznom i bez nje u istom društvu, ili između sličnih društava, od kojih neka imaju smrtnu kaznu, a druga nemaju, omogućuju zaključivanje o odvraćajućem utjecaju smrtne kazne, odnosno njegovu izostanku.

No, i u pogledu takvih istraživanja i nekih zaključaka koji su iz njih proistekli treba biti oprezan. Zbog različite metodologije, odnosno vremenskog i teritorijalnog izbora uzorka, istraživači su dolazili do dijametralno suprotnih zaključaka: od toga da svaka egzekucija sprečava 8,14 ili više novih ubojstava, do toga da egzekucije svojim poticanjem klime nasilja u društvu povećavaju broj budućih ubojstava. ${ }^{32}$ Takvi različiti rezultati akademskih istraživanja imali su i vrlo praktične posljedice. Tako je moratorij na izvršenje smrtne kazne u SAD-u između 1972. i 1976. dijelom bio inspiriran upravo rastućim sumnjama u pogledu odvraćajućih učinaka smrtne kazne, a nastavak pogubljivanja uslijedio je

31 Nije moguć, zato što u određenom trenutku, u određenom društvu, smrtna kazna ili postoji, ili ne. Bi li se pojedinac ponašao drugačije ovisno o tome je li smrtna kazna zapriječena ili ne, možemo zaključivati samo posredno i stoga ne dovoljno pouzdano.

32 Za sažetu kritiku teorijskih i metodoloških nedostataka pojedinih istraživanja provedenih nakon 2000. vidi Fagan, J., An exemination of the Death Penalty in the United States, Hearing Before the Subcommittee on the Constitution, Civil Rights and Property Rights of the Senate Committee on the Judiciary, 109th Cong., 2d Sess., 2006., str. $21-35$. 
nakon objavljivanja istraživanja koje je prognoziralo da jedno pogubljenje odvraća od počinjenja osam ubojstava. ${ }^{33}$

Kada se primijeni metodološki maksimalno strog pristup te se kontroliraju različiti faktori koji mogu biti povezani sa stopom počinjenja ubojstava i egzekucijama, zaključak je da ne postoje jasni dokazi odvraća li smrtna kazna zločine ili ne odvraća. U tome se podudaraju rezultati najobuhvatnijih i akademski najcjenjenijih ranijih istraživanja provedenih za UN ${ }^{34}$ te u SAD-u. ${ }^{35}$ Također, rezultati novijih istraživanja provedenih u raznim krajevima svijeta potvrđuju ove nalaze. ${ }^{36}$

Takvo mišljenje potvrđuje i kriminalistička struka. Anketirani vodeći kriminalisti, njih 77, u golemoj su većini (više od 90 posto) ocijenili da ne postoje dokazi da smrtna kazna ima snažnije odvraćajuće djelovanje od dugogodišnje zatvorske kazne. Čak dvostruko više smatra da pogubljenja svojim negativnim utjecajem na stvaranje opće klime nasilja zapravo povećavaju broj ubojstava. ${ }^{37}$

33 Vidi Fagan, J., Deterrence and the death penalty in international perspective, u: Šimonović, op. cit. u bilj. 12, str. 87 i citiranu literaturu. Vidi također Zimmering, Fagan, Johnson, op. cit. u bilj. 11, str. $1-29$.

34 Riječ je o istraživanju provedenom 1988. i ažuriranom 1996. Vidi Hood, op. cit. u bilj. 11, str. 238.

35 Još 1978. godine, kao odgovor na odluku Vrhovnog suda SAD-a iz 1976. da prekine četverogodišnji moratorij na izvršavanje smrtne kazne (Gregg v. Georgia (428 U.S. 153, u kojoj se citira i ekonometrijsko istraživanje koje je zaključilo da smrtna kazna odvraćajućim učincima spašava živote), Nacionalni istraživački savjet Akademije SAD-a (National Research Council) u kritički intoniranom izvješću Deterrence and Incapacitation: Estimating the Effects of Criminal Sanctions on Crime Rates zaključio je da "istraživanja nisu dovela do uporabivih dokaza o odvraćajućim učincima smrtne kazne" (str. 9). Da bi se ocijenilo jesu li u međuvremenu istraživanja dovela do čvršćih dokaza, Odbor za odvraćanje i smrtnu kaznu i Odbor za pravo i pravdu došli su do navedenog zaključka nakon vrlo obuhvatnog, interdisciplinarnog i metodološki vrlo rigoroznog istraživanja, sadržanog u izvješću podnesenom 2012. Nacionalnom istraživačkom savjetu Akademije (Deterrence and the Death Penalty, National Research Council of the National Academies, National Academic Press, Washington D. C., 2012.).

36 Ova se istraživanja odnose na istočnu Europu, Trinidad i Tobago, Tajvan i Singapur. Vidi Fagan, op. cit. u bilj. 33, str. 89. Šire vidi također Hoyle, Hood, op. cit. u bilj. 11.

37 Radelet, M.; Lacock, T. L., Do Executions Lower Homicide Rates: The Views of Leading Criminologists', The Journal of Criminal Law and Criminology, sv. 99, br. 2, 2009., str. 489 - 507. Premda su istraživanjem obuhvaćeni vodeći kriminalisti povezani s Američkim udruženjem kriminologa, s obzirom na to da je riječ o najvećem 
Zašto se onda državni i pravosudni dužnosnici često i dalje pozivaju da zadržavaju smrtnu kaznu kao nužnu mjeru za sprečavanje počinjenja najtežih kaznenih djela? Je li riječ o neznanju, tvrdoglavosti, oportunizmu ili manipulaciji? Kod nekih, posebice u zemljama u razvoju, to može biti zbog neznanja i predrasuda, ali kod drugih i zato što dužnosnici, bez obzira na to što sami u to ne vjeruju, znaju da njihovo izborno tijelo vjeruje u odvraćajuće učinke smrtne kazne. Smrtnu kaznu stoga zadržavaju iz straha da bi, ako nakon ukidanja smrtne kazne dođe do povećanja zločina, mogli za to platiti političku cijenu. Također, lakše se prikazivati kao odlučan borac protiv zločina zadržavanjem smrtne kazne nego mukotrpnim usavršavanjem kaznenopravnog sustava i njegove učinkovitosti.

Kratka ilustracija mogućih praktičnih posljedica takvog postupanja. Posljednjih godina, kao odgovor na rastuće ugroze vezane uz terorizam i drogu, neke države žele za ova djela proširiti, ili čak ako su je ranije napustile, ponovno uvesti smrtnu kaznu. I u pogledu terorizma i droge rezultati novijih istraživanja pokazuju da smrtna kazna ne djeluje odvraćajući. ${ }^{38}$ Dapače, kod terorizma učinak može biti upravo suprotan: smrtna kazna stvara mučenike i doprinosi regrutiranju novih sljedbenika. ${ }^{39} \mathrm{Uz}$ to, smrtna kazna za djela koja ne uključuju namjerno ubojstvo, prema praksi Odbora za ljudska prava, ne udovoljavaju kriteriju "najtežih djela" te time predstavlja kršenje čl. 6. Međunarodnog pakta o građanskim i političkim pravima iz 1966.

- Što je pak s argumentom pravde, posebice pravde za žrtve? Povijesno, mnoge vizije pravde, primjerice one koje se zasnivaju na odmazdi s obzirom na težinu počinjenog djela, odnosno stupanj krivnje njegova počinitelja, za najteža djela zahtijevale su smrtnu kaznu. Ovakve vizije pravde mogu biti poduprte vjerskim i kulturnim normama (odnosno njihovom odgovarajućom interpretacijom), ili vezivanjem pravde uz udovoljenje žrtvama, odnosno njihovim obiteljima i drugim bliskim osobama.

Kod religija nije riječ samo o tome predviđaju li njihove norme smrtnu kaznu ili ne, već o cjelovitoj religijskoj interpretaciji. ${ }^{40}$ Tako činjenica

udruženju koje obuhvaća oko 3500 kriminologa iz 50 država, rezultati se mogu smatrati indikativnim za kriminalističku struku općenito. Vidi Fagan, op. cit. u bilj. 33, str. 90 - 96 i citiranu literaturu.

U oba slučaja, prema judikaturi UN-ova Odbora za ljudska prava, smrtna kazna za djela koja ne uključuju namjerno lišavanje života ne doseže prag "najtežih djela” te je u suprotnosti s međunarodnom zaštitom ljudskih prava.

40 Tako Marazziti primjerice smatra da, premda su vjerska tijela često zagovarala smrtnu kaznu, glavna vjerska učenja prevladavajuće zagovaraju neoduzimanje života. 
da Biblija u Starom zavjetu zagovara smrtnu kaznu kao odmazdu nije spriječila Katoličku crkvu da već dulje zagovara moratorij na njezino izvršavanje. Papa Franjo čak je nedavno inicirao i formalnu promjenu Katekizma koja smrtnu kaznu proglašava protivnom kršćanskom nauku. Premda Kuran izričito predviđa smrtnu kaznu za pojedina djela, njegovi stihovi da je ubiti nevinog čovjeka jednako kao pobiti čitavo čovječanstvo mogu se protumačiti kao zabrana njezina izvršavanja zbog mogućnosti pogreške. ${ }^{41}$

Argument pak pravde za žrtve sve je prije nego jednoznačan ${ }^{42}$ Dio žrtava, odnosno njihovih obitelji, volio bi smrtnu kaznu za počinitelja, ali drugi dio ne bi. Uz to, odnos obitelji žrtvi spram smrtne kazne može se kroz vrijeme mijenjati.

Neke žrtve, odnosno njihove obitelji, odbacuju izvršavanje smrtne kazne u njihovo ime. Smatraju da se smrtnom kaznom nastavlja krug nasilja, umjesto da ga se prekine, te stoga odbijaju da se smrtna kazna izvršava u njihovo ime. U obiteljskom kontekstu često dolazi do razdora između članova obitelji koji smrtnu kaznu žele ili ne žele. To pogotovo dolazi do izražaja ako članovi obitelji svojim svjedočenjem o učincima djela na njih i njihov život mogu utjecati na visinu i vrstu kazne za počinitelja. ${ }^{43}$ Oni članovi obitelji koji žele smrtnu kaznu često smatraju one koji je ne žele izdajicama, pa se njihovi odnosi kvare ili čak pucaju. Tako se žrtve, odnosno njihove obitelji, viktimizira drugi put.

Dodatne komplikacije pojavljuju se kada su i počinitelj i žrtva članovi iste obitelji, što je razmjerno često. ${ }^{44}$ Dobra je ilustracija slučaj kada je majka

Vidi Marazziti, M., World religions and the death penalty, u: Šimonović, op. cit. u bilj. 15, str. $192-203$.

41 Za ovakvo tumačenje vidi Marzouki, M. M., Challanges related to abolition of the death penalty in Arab and Islamic countries: Tunisia's model, u: Šimonović, op. cit. u bilj. 15, str. 275.

42 Bolje razumijevanje odnosa žrtava spram smrtne kazne važno je jer utječe na stav opće populacije spram smrtne kazne (vidi o tome King, R., Don't Kill in Our Names, Rutgers University Press, New Bruswick, New Jersey, 2003.). Tako su prema nedavnom istraživanju retribucija i osjećaji obitelji žrtava najprihvaćeniji razlozi za zadržavanje smrtne kazne u Japanu (vidi Sato, M.; Bacon, P., The Public Opinion Myth: Why Japan retains the death penalty, The Death Penalty Project, London, 2015., str. 29).

43 Primjerice u SAD-u to je takozvani victim impact testimony, vidi Madeira, J. L., Escaping the closure gap, u: Šmonović, op. cit. u bilj. 12, str. 66.

44 U Japanu su počinitelji ubojstava članovi obitelji u oko pola slučajeva. Vidi Tagusari, M., Does the death penalty serve victims?, u: Šimonović, op. cit. u bilj. 12, str. 44. 
koja je naručila ubojstvo njihova oca željela prije pogubljenja vidjeti svoje dvoje djece i zamoliti ih za oprost. ${ }^{45}$ Kćer koja je prihvatila susret nakon njega je dugo patila od depresije. Sin koji je odbio vidjeti majku prošao je još gore: nakon njezina pogubljenja počinio je samoubojstvo.

No, donosi li postojanje smrtne kazne utjehu barem za žrtve koje bi željele pogubljenje počinitelja? Za mnoge svakako ne. ${ }^{46}$ Primjerice, u SAD-u se samo otprilike $1-2$ posto namjernih ubojstava kažnjava smrtnom kaznom, od čega pak samo polovina bude i izvršena. ${ }^{47}$ Podaci su slični za Japan, a u Indiji je vjerojatnost da ubojstvo bude kažnjeno izricanjem smrtne kazne tek $0,3 \%{ }^{48}$ To predvidivo znači da velika većina onih žrtava koje žele smrtnu kaznu za počinitelje ostaje frustrirano. Muči ih pitanje: ako su neki za slična djela kažnjeni smrtnom kaznom, zašto ubojica njihove voljene osobe nije? Po čemu je njihova žrtva manje vrijedna?

Dodatno, stručnjaci upozoravaju da puno sporije odlučivanje o smrtnoj kazni i njezinu izvršenju nego što je to slučaj kod ostalih kazni odgađa osjećaj završetka nesretnog životnog ciklusa, a time produžuje napetost i pritisak na obitelji žrtava. ${ }^{49}$ Postojanje smrtne kazne za obitelji žrtava koje žele njezino izvršenje stoga je "poput čaše slane vode za žednog čovjeka". ${ }^{50}$ Suprotni primjer: Bud Welch, otac jedne od žrtava podmetanja bombe u Oklahoma Cityju, nakon dugotrajne razarajuće želje za odmazdom, smirio se tek kad je prihvatio da je "opraštanje dar koji daruješ samome sebi". ${ }^{51}$

45 Vidi Sharp, op. cit. u bilj. 12, str. 182.

46 Johnson navodi kako je još prije 2500 godina Konfucije upozorio: "Prije nego što kreneš putem osvete, iskopaj dva groba." (Johnson, D. T., Does capital punishment bring closure to the victims?, u: Simonović, op. cit. u bilj. 12, str. 82).

47 Vidi Tagusari, op. cit. u bilj. 44, str. 41. Tagusari se također poziva na izvješće Ministarstva pravosuđa Japana prema kojem bi, kada je riječ o ubojstvu u obitelji, dvije trećine članova obitelji oprostilo počinitelju.

48 Vidi Lehrfreund, S.; Hood, R., The inevitability od arbitrariness: another aspect of victimization in capital punishment laws, u: Šimonović, op. cit. u bilj. 12, str. 151.

49 Drugi pak upozoravaju da nije riječ o završetku, već o odgađanju procesa oporavka jer žrtve često do kraja života barem do određene mjere pate zbog gubitka. Vidi primjerice Johnson, op. cit. u bilj. 46, str. 77.

50 Vidi Prejean, H., Death penalty: victims' perspective, u: Šimonović, op. cit. u bilj. 12, str. 187.

51 Vidi Madeira, op. cit. u bilj. 43, str. 68. 


\subsection{Novi argumenti}

Noviji istraživački rezultati, osim što osnažuju klasične argumente protiv i slabe argumente za zadržavanje smrtne kazne, upućuju i na neke nove argumente. Oni se u prvom redu odnose na proširivanje kruga osoba koje trpe negativne posljedice smrtne kazne te na negativne učinke smrtne kazne na društvo općenito.

Ako su učinci smrtne kazne na žrtve i njihove obitelji u najmanju ruku dvojbeni, negativni učinci na nevine tré́e osobe sasvim su nedvojbeni. Oni posebno pogađaju obitelj osuđenog i druge bliske osobe, ali i sve one koji sudjeluju u postupku odlučivanja o smrtnoj kazni i njezinu izvršenju.

- Smrtna kazna pogađa obitelj osuđenog daleko snažnije nego bilo kakva druga vrsta kazne. Obitelji, a posebice najbliže osobe i djeca na smrt osuđenih, znatno češće su pogođene PTSP-om te drugim psihičkim problemima nego obitelji osuđenih na druge, uključujući i najduže zatvorske kazne. Koji su razlozi za to? Tri mi se čine posebno važnima.

o Prvo, pritisak vezan uz odlučivanje o smrtnoj kazni i njezinu izvršenju može trajati kroz dulje vrijeme. Izmjena ciklusa proturječnih emocija straha i nade do kojih dolazi tijekom sudskog postupka, presuda, žalbi te molbi za odgodu izvršenja kazne psihički je iznimno iscrpljujuća. U ciklus se u trenucima beznađa i iscrpljenosti obitelji često upliće i želja da se sve napokon završi, što kasnije može izazvati i snažan osjećaj krivnje. ${ }^{52}$

Cjelokupna obiteljska situacija na smrt osuđenih ili pogubljenih posebno se negativno odražava na djecu. Manja djeca jednostavno ne mogu razumjeti što se događa, zašto jednog roditelja nema, a drugi stalno plače, zašto više ne mogu živjeti kao prije, a adolescenti odbijaju prihvatiti situaciju u kojoj su se našli te osjećaju bijes u odnosu na člana obitelji koji je počinio djelo i doveo ih u tešku situaciju ${ }^{53}$, ali i u odnosu na društvo. Zabrinuto za djecu, Vijeće za ljudska prava Ujedinjenih naroda usvojilo je 2013. rezoluciju 22/11 o ljudskim pravima djece čiji su roditelji osuđeni na smrt ili pogubljeni, pozivajući države da uzmu u obzir negativne posljedice koje pogađaju djecu te im osiguraju zaštitu i pomoć u skladu s Konvencijom o pravima djeteta. Panel Vijeća

52 Vidi opširnije Sharp, op. cit. u bilj. 12, str. 184 - 189 te Joy, S., Socio-Psychological Challenges of "Death Row families", u: Šimonović, op. cit. u bilj. 12, str. 229 - 237 i citiranu literaturu.

Zbog toga često osjećaju krivnju, što se na njih dodatno negativno odražava. 
za ljudska prava održan na istu temu pola godine kasnije uključio je i diskusije o tome da bi prilikom odlučivanja o kazni trebalo uzeti u obzir učinke na djecu te ljudska prava djece te da osuda na smrt roditelja potencijalno vrijeđa prava djece. ${ }^{54}$

o Drugo, bol obitelji uglavnom ostaje nepriznata od strane okoline. Društvena stigma koja i inače prati počinitelje najtežih kaznenih djela najjača je u odnosu na osuđene na smrt, a time i pritisak na njihove obitelji da osude ne samo djelo, nego i da se na neki način distanciraju od počinitelja. Kako se smrtna kazna izriče samo za najteža djela, percepcija je da su onda i njihovi počinitelji najgori od najgorih. U očima okoline, pa tako i prijatelja i susjeda, članovi obitelji često se doživljavaju kao sukrivci zbog svoje povezanosti s počiniteljem. Pritisak da biraju: odreći se bliske osobe ili živjeti u sukobu s društvenom okolinom često dovodi do dubokih psihičkih konflikata i negativnih zdravstvenih posljedica.

o I konačno treće. Negativni psihološki te društveni i gospodarski učinci na obitelj međusobno se isprepliću. Povećani troškovi obrane tijekom dugogodišnjih pravnih postupaka gospodarski iscrpljuju obitelj, a njihovo psihičko stanje i socijalna izolacija negativno se odražava i na njihove mogućnosti privređivanja. Primjeri posljedica uključuju i zlostavljanje u školi i na poslu, uništavanje imovine, odmazdu nad kućnim ljubimcima i slično, uslijed čega su se neke obitelji morale i odseliti. ${ }^{55}$ Napokon, primjer posebno drastičnog slučaja. Optuženi za ubojstvo supruge prodao je kuću i vozila da osigura kvalitetnu obranu, no to nije bilo dovoljno, pa su i njegovi roditelji morali založiti kuću. Nisu se, međutim, mogli brinuti za njegove dvije djevojčice, pa su one posvojene. Kada je osuđeni na smrt kasnije ipak oslobođen, osiromašio je ne samo on već i obitelj, nije više uspio ostvariti pravu vezu s biološkom djecom te je shrvan posljedicama umro nekoliko godina kasnije.

- Premda ne u tolikoj mjeri, sudionici u postupku koji vodi izricanju smrtne kazne i njezinu izvršenju također su izloženi psihološkom stresu koji ostavlja posljedice. Krug potencijalno pogođenih osoba vrlo je širok i uključuje sudionike pravnog postupka koji vodi izricanju smrtne kazne: suce, tužitelje i odvjetnike, osobe koje su dužne brinuti se za osuđenog dok čeka izvršenje presude, primjerice svećenike te zatvorsko osoblje koje

54 Vidi opširnije SSuubi, F., The impact of the death penalty on the children with a parent on death row or executed, u: Šimonović, op. cit. u bilj. 12, str. $190-205$.

55 Za primjer vidi Sharp, op. cit. u bilj. 12, str. 177 - 181. 
sudjeluje u čuvanju na smrt osuđenog i pri njegovoj egzekuciji. Kod svih njih može se pojaviti sekundarna trauma vezana uz pogubljenja.

o Posebice su pogođeni oni koji neposredno sudjeluju u egzekuciji i koji su znali doživljavati simptome svojstvene PTSP-u, poput problema sa zdravljem, depresijom, ovisnostima te razmišljati o samoubojstvu. ${ }^{56}$ Sudionike $\mathrm{u}$ izvršavanju smrtne kazne nastoji se $\mathrm{u}$ nekim sustavima zaštititi od psihičkih posljedica rastavljanjem procesa izvršenja u niz jednostavnih zadataka uz minimiziranje kontakta s osuđenikom, čime se osjećaj osobne odgovornosti za ishod nastoji zamijeniti s doživljajem sudjelovanja u izvršavanju zajedničkog zadatka. Tako jedan od devet sudionika egzekucije opisuje da je njegov posao "desna noga". Zavrne nogavicu gore, stavi elektrodu i zavije ju. ${ }^{57}$ Ipak, ni taj trik često ne pomaže. Sudionik u višekratnom izvršavanju smrtne kazne svake je noći sanjao ljude u čijoj je egzekuciji sudjelovao kako sjede na rubovima njegova kreveta i nijemo ga gledaju. ${ }^{58}$ Odao se alkoholu, napustio je posao upravitelja zatvora do kojeg je uznapredovao i tek se nakon psihijatrijskog liječenja i uključivanja u abolicijske aktivnosti uspio oporaviti. Poruka ovog čovjeka koji je sudjelovao u oduzimanju mnogih života i zbog toga se danas kaje jest da "nema humanog načina da se oduzme život”. Drugi je sudionik u egzekucijama izjavio da se nakon pogubljenja "osjećao prljavim” i da svaki put kada sudjeluje u nečijem pogubljivanju dio njega također umire. ${ }^{59}$

o No, nisu pogođeni samo oni koji sudjeluju u izvršavanju smrtne kazne, već i oni koji su u raznim ulogama sudjelovali u postupcima koji su prethodili njezinu izvršenju. Tako se, primjerice, odvjetnik iz Japana čiji je klijent pogubljen nije mogao prestati opterećivati krivnjom da je mogao tijekom obrane napraviti više. Mjesecima nije normalno spavao, često je sanjao bivšeg klijenta, slabo jeo i bio u depresiji. Odvjetnik iz SAD-a pak navodi kako je bilo posebno opterećujuće priopćiti klijentu da će biti pogubljen i suočiti se s njegovim optužbama da ga je iznevje-

56 Vidi Seal, L.; Seemungal, F.; Black, L., Death Penalty and Its Impact on the proffesionals involved in the execution process, u: Šimonović, op. cit. u bilj. 12, str. $249-250$.

57 Vidi Johnson, R., Executioners at work: Colateral Consequences of executions for Officers Working on Death Row and in the Death House, u: Šimonović, op. cit. u bilj. 12, str. 269 -272 .

58 Prema njegovu izlaganju na tribini u UN-u u New Yorku koju sam vodio. Nešto drukčija verzija u članku McAndrew, R., Painful then, painful now, u: Šimonović, op. cit. u bilj. 12, str. 281.

59 Vidi Seal, Seemungal, Black, op. cit. u bilj. 56, str. 251. 
rio, posljednji ga put posjetiti, najaviti pogubljenje obitelji te odlučiti

hoće li ostati s klijentom do kraja i prisustvovati pogubljenju. ${ }^{60}$

- Činjenica da smrtna kazna pogađa tolike navela me da u knjizi "Smrtna kazna i žrtve" proširim pojam žrtava smrtne kazne tako da obuhvati ne samo obitelji žrtava zločina, već i sve ostale čija su ljudska prava pogođena primjenom smrtne kazne, njezinom brutalnošću i traumatskim učincima. U njih se pod određenim okolnostima mogu ubrojiti i same žrtve, odnosno njihove obitelji, osuđeni, ako su povrijeđena njihova ljudska prava (jer su, primjerice, nevini, žrtve diskriminatorne primjene ili postupovnih pogreški, pripadaju krugu osoba kojima se ne smije izreći smrtna kazna ili im je kazna izrečena za djela za koja se ona po međunarodnom pravu ne bi smjela izricati) te napokon treće nevine osobe, uključujući obitelji osuđenih i sudionike u postupku odlučivanja o smrtnoj kazni i njezinu izvršenju. Najviši predstavnici Svjetskog viktimološkog društva takvo su prošireno definiranje žrtava podržali te i sami dali doprinos knjizi svojim prilogom. ${ }^{61}$

- Ali, možemo li propitivati i dalje? Nisu li možda svi osuđeni na smrt žrtve? Tako bi se moglo zaključiti prema judikaturi Europskog suda za ljudska prava. Nakon duge evolucije u svojoj judikaturi Europski je sud za ljudska prava napokon zaključio da smrtna kazna uvijek vrijeđa ljudska prava (premda Europska konvencija u svojem tekstu izričito pod određenim uvjetima dopušta smrtnu kaznu). ${ }^{62}$ U sličnom bi smjeru u budućnosti mogao odlučiti i Afrički sud za ljudska prava te proglasiti smrtnu kaznu kršenjem Povelje Afričke unije, posebice prava na dostojanstven život.

- Ili još dalje: Nije li možda svaki pripadnik društva u kojem postoji smrtna kazna na neki način njezina žrtva?

60 Sheffer, S., Fighting for clients' lives: the impact of death penalty work on post-conviction capital defence attorneys, u: Šimonović, op. cit. u bilj. 12, str. 288 - 291.

${ }_{61}$ Predsjednik i tajnik Svjetskog viktimološkog društva suautori su članka objavljenog na samom početku spomenute knjige, koji pomaže tumačenju pojmova, odnosno potrebi njihove promjene. Vidi Groenhuijsen, M.; O'Connell, M., Arguments against the death penalty as seen from a victimological perspective, u: Šimonović, op. cit. u bilj. 12, str. $22-40$.

${ }^{62}$ To je zanimljivo stoga što budi nadu da bi u budućnosti moglo tako biti tumačeno i pravo na život iz članka 6. Pakta o građanskim i političkim pravima, bez obzira na stavak 1. koji pod određenim okolnostima dopušta smrtnu kaznu. Tome bi moglo pomoći i odgovarajuće tumačenje članka 7. Pakta o zabrani mučenja te okrutnog, nehumanog i ponižavajućeg postupanja, čemu je Odbor za ljudska prava već još bliže. 
Na apstraktno postavljeno moralno pitanje: imaju li svi, uključujući i počinitelje najgnusnijih zločina, neupitno pravo na život, naša se mišljenja mogu razlikovati. No, čak ako i prihvatimo da počinitelji najtežih zločina možda u moralnom smislu ne zaslužuju živjeti, komu bi se, pod kakvim uvjetima i uz kakvu cijenu u stvarnom životu moglo dati pravo da im oduzme život? Osobno smatram da državi nije dobro dati pravo da oduzima život iz dva osnovna razloga. ${ }^{63}$

o Prvi je da se ovlašću državi da pod određenim uvjetima oduzima život šalje pogrešna poruka. Društvo koje doista poštuje život ne ubija namjerno ljudska bića. Ako je državi pod nekim uvjetima dopušteno da ubije, to znači da namjerno oduzeti ljudski život nije uvijek pogrešno. Kroz državno sankcionirano oduzimanje života u moralnom se smislu relativizira univerzalnost zabrane njegova oduzimanja. Ako država može oduzimati život, onda odlučivanje o tome tko će, kada i pod kojim uvjetima biti ovlašten na oduzimanje života ovisi o interesima i raspodjeli moći u društvu.

o S tim je povezan i drugi razlog. Smrtna kazna dio je šireg idejnog i političkog sklopa koji naglašava kult države, njezin monopol sile te suverenu vlast sa širokim prerogativima, uključujući i pogubljivanje vlastitih državljana. Sve dok smrtna kazna postoji, postoji i mogućnost njezine zloupotrebe. ${ }^{64}$ Što je država manje demokratska te što je više autoritarna, takva je mogućnost veća.

Kako je u literaturi odnos između autoritarnosti ili demokratičnosti društva i smrtne kazne još prilično neobrađen, a smatram ga vrlo značajnim, posvetit ću mu nešto više prostora. Povijesno, abolicija je znala biti povezana uz raskid s represivnom prošlošću, kao što je to primjerice bio slučaj nakon aparthejda u Južnoj Africi, genocida u Ruandi, zaključivanja mirovnog ugovora u Kambodži ili urušavanja Duvalierova režima u Haitiju. Argentina,

63 Vidi opširnije Šimonović, op. cit. u bilj. 26, str. 15 - 18. O pitanju moralnosti postupanja pri kojem se život oduzima depersonalizirano, hladno i proračunato, a da pri tome nitko za to ne preuzima osobnu odgovornost, vidi također Deterrence and the Death Penalty, National Research Council of the National Academies, National Academic Press, Washington D. C., 2012.

64 Tako bivši pakistanski ministar za nacionalnu slogu i manjinska pitanja navodi da se u najgorim pravosudnim sustavima smrtna kazna koristi za obračun s vjerskim i političkim manjinama u ime ekstremističkih ideologija i planova. Ali u uvjetima političkih nemira, rata, gladi i bijede i najbolji se pravosudni sudovi mogu izokrenuti u najgore, pretvarajući postojanje čak i s dobrim namjerama uspostavljene smrtne kazne u potencijalnu minu. 
Meksiko i Turska napustili su smrtnu kaznu nakon završetka izvanrednog stanja ili nakon što su ukinuti vojni sudovi. ${ }^{65}$

No, možemo li osim ilustrativnih povijesnih primjera pouzdanije empirijski utvrditi kakva je veza izmedu stupnja demokratičnosti odnosno autoritarnosti i smrtne kazne? U nedostatku odgovarajućih istraživanja i njihovih rezultata na tu temu, proveli smo sami kratku provjeru zasnovanu na usporedivim podacima za 2018. godinu. Promotrimo listu država koje najviše pogubljuju. ${ }^{66}$ Prva je uvjerljivo, ako se uzmu u obzir službeno registrirana, a još više ako se uključe i neregistrirana pogubljenja, Kina. Za njom kao sljedeće četiri slijede Iran, Saudijska Arabija, Vijetnam i Irak, u kojima se, ako se isključi Kina, pogubi 78 posto svih pogubljenih drugdje u svijetu. ${ }^{67}$

Usporedimo navedenu listu država koje najviše pogubljuju s rang-listom država prema njihovoj demokratičnosti, odnosno autoritarnosti. Od 2006. Economist Intelligence Unit provodi takvo rangiranje na temelju 60 različitih indikatora. Države se rangira prema broju bodova te svrstava u četiri kategorije: pune demokracije, demokracije s greškama, hibridne režime $i$ autoritarne režime.

Kako su 2018. poredane i svrstane države koje su najviše pogublivivale iste godine? Od 167 rangiranih država Kina je po stupnju demokratičnosti 130. Iran 150., Saudijska Arabija 160., Vijetnam 139., a Irak 114. Kina, Iran, Saudijska Arabija i Vijetnam svrstani su u autokratske režime, a samo Irak, i to po broju bodova za dlaku, u hibridne. ${ }^{68}$

Kontrole radi, razmotrili smo i države na vrhu ljestvice. Ne samo da je prvih pet - Norveška, Island, Švedska, Novi Zeland, Danska i Irska - ukinulo smrtnu kaznu, već je to učinilo svih prvih 20 na ljestvici. ${ }^{69}$ To je ujedno jedinih dvadeset država svrstanih kao pune demokracije.

65 Vidi How States Abolish the Death Penalty: 29 Case-Studies, International Commission Against Death Penalty, 2018., str. 11.

66 Izvor je Amnesty International global report: Death sentences and executions 2018, Amnesty International 2019.

${ }^{67}$ Možda bi rang-ljestvica izgledala drukčije da broj pogubljenih u Demokratskoj Narodnoj Republici Koreji nije službena tajna.

68 Demokratska Narodna Republika Koreja je 167. i najautoritarnija je država.

${ }_{69}$ Od 6. do 20. mjesta poredane su Kanada, Finska, Australija, Švicarska, Nizozemska, Luksemburg, Njemačka, Ujedinjeno Kraljevstvo, Urugvaj, Austrija, Mauricijus, Malta, Španjolska i Kostarika. 
Zar je slučajno da postoji tako visoka korelacija između stupnja autoritarnosti država i njihove sklonosti smrtnoj kazni? ${ }^{70}$ Zar je slučajno da porast autoritarnosti pojedine države dovodi u pitanje dotadašnja dostignuća u napuštanju smrtne kazne? ${ }^{71}$ Zar je slučajno da se u najautoritarnijim državama po demokratskim pravilima igre potpuno legitimnu opoziciju te stvarne ili zamišljene protivnike autoritarne prakse naziva izdajnicima, teroristima i državnim neprijateljima, pa čak i pogubljuje? ${ }^{72}$

Po mojem sudu društveni ugovor između pojedinaca i države u 21. stoljeću više ne bi smio uključivati smrtnu kaznu. Upravo one države, odnosno državne elite koje bi je željele zadržati, opasne su da bi je mogle zloupotrijebiti. Uz to, smrtna kazna sastavni je dio klime nasilja u društvu koja pogoduje i drugim tipovima kršenja ljudskih prava od strane države, poput torture, u slučajevima kada su "državni interesi" - onako kako ih često proizvoljno definiraju oni na vlasti - u pitanju.

70 Ovu, nedvojbeno visoku korelaciju, mogli bismo još preciznije kvantificirati. Trebalo bi samo sve države rangirati prema njihovu odnosu spram smrtnoj kazni (abolirale smrtnu kaznu, proglasile moratorij na izvršenje, provode de facto moratorij, izvršavaju smrtnu kaznu) te usporediti s rangiranjem država prema njihovoj demokratičnosti, odnosno autoritarnosti (za to bi kontrole radi mogli iskoristiti dva najuvažavanija indeksa Economist Intelligence Unita i Freedom Housea). Ono što bi bilo posebno interesantno za kvalitativnu analizu su odstupanja; zašto neke države koje su razmjerno visoko na ljestvici demokratičnosti, poput Koreje, ipak ne ukidaju smrtnu kaznu ili je čak još uvijek izvršavaju (Japan, SAD). Također bi bilo zanimljivo provjeriti ima li detaljniji uvid u neke od indikatora ili skupina indikatora na kojima su zasnovani indeksi bolju prognostičku vrijednost od indikatora $\mathrm{u}$ cjelini i zašto.

71 I u državama u kojima je smrtna kazna napuštena u takvim se okolnostima ponekad ponovno navješćuje njezino moguće uvođenje kao što je to slučaj s Turskom. Prema Freedom House u Turskoj je u posljednjih 10 godina demokracija najviše nazadovala (Freedom in the World 2018 report, the Annual Survey of Political Rights and Civil Liberties, Freedom House, New York and Washington, 2019.). Bilo bi zanimljivo istražiti dinamiku u kojoj se mjeri promjene na ljestvicama demokratičnosti pojedinih država odražavaju na njihov odnos spram smrtne kazne. Time bi istraživanje spomenuto u prethodnoj fusnoti dobilo i dinamičku komponentu te omogućilo testiranje prognostičke vrijednosti hipoteza koje bi se iz njega mogle izvesti.

72 Ne moramo se vraćati u tom pogledu na staljinističku Rusiju. Drastičan suvremeni primjer za to je Demokratska Narodna Republika Koreja, a našlo bi ih se, nažalost, još. 


\section{KAKO PROTIV SMRTNE KAZNE?}

\subsection{Načini napuštanja}

Povijesno i komparativno gledano, načini na koje su države napuštale smrtnu kaznu bili su vrlo različiti. Znatne su bile razlike i u brzini odmicanja, i u načinima kako se to ostvarivalo.

- U nekim je državama proces bio postupan, započinjući s ograničavanjem mogućnosti izricanja i izvršavanja smrtne kazne, preko de facto moratorija i njegova službenog proglašenja, sve do abolicije. Kod drugih, posebice nakon političkih promjena, kraja represivnih režima ili vojnih diktatura, napuštanje je bilo brzo i radikalno. ${ }^{73} \mathrm{U}$ pravno-tehničkom smislu napuštanje se provodilo kroz praksu zamjene smrtne kazne i sveobuhvatnih pomilovanja $^{74}$, promjena zakona, ustava ili sudske prakse, odnosno proglašenja smrtne kazne protivnom Ustavu. ${ }^{75}$ Napokon, osim kroz promjene u nacionalnom pravnom sustavu, neke su države odlučile da i prije formalnog ukidanja smrtne kazne pristupe međunarodnim instrumentima koji traže njezino ukidanje. ${ }^{76}$

- Za odlučivanje o napuštanju smrtne kazne vrlo je važno što se nudi kao njezina alternativa. U praksi se pokazalo da se najlakše pristaje zamijeniti smrtnu kaznu kaznom doživotnog zatvora bez mogućnosti pomilovanja. Tako često i u društvima u kojima je jača podrška smrtnoj kazni nego njezinoj aboliciji, na primjer u SAD-u, ako se smrtnoj kazni kao alternativa postavi kazna doživotnog zatvora bez mogućnosti pomilovanja, takvu zamjenu podržava većina populacije. ${ }^{77}$ Osobno mi je i kazna doživotnog

73 Opširnije vidi How States Abolish the Death Penalty: 29 Case-Studies, International Commission Against Death Penalty, Madrid, 2018.

74 Za primjer Tunisa vidi Marzouki, op. cit. u bilj. 41, str. 272 - 275.

75 Južna Afrika najpoznatiji je slučaj napuštanja smrtne kazne proglašenjem njezine suprotnosti s Ustavom jer vrijeđa ljudska prava. Od novijih primjera, odluke Ustavnog suda u Gvatemali iz 2016. i 2017. doprinijele su njezinu napuštanju (vidi opširnije How States Abolish the Death Penalty: 29 Case-Studies, International Commission Against Death Penalty, Madrid, 2018., str. 27 - 29), a očekujem da bi Ustavni sud mogao imati važnu ulogu i u Republici Koreji.

76 Najpoznatiji takav slučaj je pristupanje Mongolije Drugom opcijskom protokolu na Pakt o građanskim i političkim pravima. O slučaju Mongolije vidi opširnije u Šimonović, op. cit. u bilj. 15, str. $266-267$.

77 Vidi, primjerice, rezultate Gallupova istraživanja za SAD iz 2019. Te godine, prvi put od 1985. otkad se takva istraživanja provode, u SAD-u se većina opredijelila protiv smrtne kazne. 
zatvora bez mogućnosti pomilovanja neprihvatljiva, jer ubija nadu $u$ mogućnost preodgoja i živoga čovjeka zatvara u grob, te smatram da je protivna ljudskim pravima. No, i ona je bolja od smrtne kazne. Barem za nevino osuđene, nada o oslobađanju živi i dalje, a manje pogađa i nevine treće osobe (obitelj osuđenika, sudionike u procesu izricanja i izvršavanja kazne). Napokon, premda se u danom trenutku može inzistirati na nemogućnosti pomilovanja, nitko ne može u apsolutnom smislu obvezati buduće generacije, čiji će stupanj humanosti, nadajmo se, biti viši od onog sadašnjih generacija.

- U globalnom odmicanju od smrtne kazne važnu je ulogu imao široki krug istomišljenika na ovom području, bili oni uključeni u nacionalne organe, međunarodne organizacije ili civilno društvo kao dužnosnici, službenici, aktivisti ili eksperti. Posebno su napuštanju smrtne kazne znale doprinijeti razne profesionalne udruge poput odvjetničkih komora i medicinskih udruga, vjerske i humanitarne udruge, nacionalne institucije za ljudska prava te pravni fakulteti i kriminalistička i kriminološka društva. ${ }^{78}$

- U napuštanju smrtne kazne bitnu ulogu ima i evolucija političkog i međunarodnopravnog okvira kroz UN i regionalne međunarodne organizacije. Tijekom ove evolucije političke aspiracije postupno prerastaju u pravo.

o UN-ova Opća deklaracija o ljudskim pravima iz $1948 .{ }^{79}$ u članku 3. jamči pravo na život. Ovo je pravo donekle ograničeno kasnijim izuzetkom, uključenim u čl. 6. Međunarodnog pakta o građanskim i političkim pravima iz 1966., koji se odnosi na smrtnu kaznu. Ipak, odredba je tako intonirana da upućuje na to da se zagovara napuštanje smrtne kazne te nameće niz uvjeta pod kojima smrtna kazna može još uvijek biti dopuštena. Odbor za ljudska prava, tijelo sastavljeno od nezavisnih eksperata da tumači konvenciju, u svojoj je praksi tumačilo dopuštenost smrtne kazne sve restriktivnije. Napokon, 1989. godine usvojen je te otvoren za prihvaćanje i ratifikaciju tekst Drugog opcijskog protokola na Pakt, usmjeren na aboliciju smrtne kazne. ${ }^{80}$ Zanim-

78 To, međutim, nije uvijek i svuda slučaj. Tamo gdje je smrtna kazna dio političke ideologije, neke je akademske institucije podupiru bez obzira na nalaze istraživanja o smrtnoj kazni i njezinim učincima te mogu i doprinijeti njezinu zadržavanju. Predavanja i razgovori o smrtnoj kazni u Bjelorusiji bili su za mene u tom smislu otrežnjavajući.

79 Deklaracija je politički, a ne pravni dokument, ali je kasnijim međunarodnim sporazumima te uključivanjem u nacionalna zakonodavstva sve više postajala i pravni.

80 Protokol obvezuje države stranke na aboliciju, uz moguću rezervu za najteža djela počinjena u vrijeme rata. Do listopada 2019. ovaj je Protokol ratificiralo 88 država stranaka. 
ljivost ovog Protokola je i njegova ireverzibilnost: kako ne predviđa mogućnost njegova otkazivanja, države koje su ga prihvatile odrekle su se mogućnosti ponovnog uvođenja smrtne kazne. ${ }^{81}$

Uz Pakt i Protokol kao pravne instrumente, UN je usvajao i političke akte o smrtnoj kazni. ${ }^{82}$ Tako, primjerice, rezolucija Opće skupštine 2857 (XXVI) iz 1971. poziva države da postupno sužavaju broj kaznenih djela za koje se može izreći smrtna kazna s ciljem njezina ukidanja u svim državama. ${ }^{83}$ Posebni učinak imao je niz rezolucija o moratoriju na smrtnu kaznu. Potaknuta od civilnog društva, Italija je 1994. podnijela Općoj skupštini rezoluciju kojom se poziva države koje to još nisu učinile da proglase moratorij na izvršavanje smrtne kazne sa svrhom njezina postupnog ukidanja. Rezolucija na glasovanju te godine nije dobila dovoljnu podršku, ali ovaj neuspjeh nije obeshrabrio njezine pobornike. Od 1997. Italija je počela uspješno podnositi rezoluciju o moratoriju na UN-ovu Komisiju za ljudska prava. Od 2007. Rezolucija o moratoriju redovito se podnosi i usvaja na trećem odboru te u plenumu Opće skupštine UN-a. Uz neznatne oscilacije podrška rezoluciji je kroz vrijeme jačala ${ }^{84}$ Napokon, UN-ovo Vijeće za ljudska prava (kao osnaženi nasljednik Komisije za ljudska prava) redovito organizira skupove i donosi rezolucije kojima poziva na napuštanje smrtne kazne. Države članice UN-a tijekom univerzalnog redovitog pregleda daju preporuku da napuste smrtnu kaznu svim onim državama koje to još nisu učinile. Isto čine i neovisna ekspertna tijela UN-a koja prate provedbu obveza koje proizlaze iz različitih konvencija o ljudskim pravima te posebni izvjestitelji nadležni za pojedina tematska područja ili države.

- Gledajući sveukupno, pritisak u UN-ovu sustavu na napuštanje smrtne kazne raste i potiče države članice u tom smjeru. Što se regija tiče, najdalje

81 Čini se vjerojatnim da je takav učinak postignut bez izričite namjere: zaokupljeni sadržajem, njegovi su tvorci i države članice jednostavno zaboravili na procesnu odredbu o uvjetima otkazivanja. To se pokazalo kao dvosjekli mač: s jedne strane otežalo je povratak smrtne kazne u državama strankama, ali i - nakon što se proširila spoznaja o ireverzibilnim učincima - otežalo pristup novih država Protokolu.

82 Ovi politički akti, međutim, nisu pravno obvezujući ni za koju državu, ali jesu politički obvezujući za države koje su ih prihvatile.

83 Usvojena s 59 glasova za, 1 protiv i 54 suzdržanih.

84 Razina podrške rezolucijama po godinama nije sasvim usporediva zbog razlika u njihovu sadržaju. Kod svakog novog podnošenja pojavljivala se dilema izazvana oprečnim težnjama za što snažnijim sadržajem rezolucije i njezinim što širim prihvaćenjem. 
su u napuštanju smrtne kazne doprle Europa te Srednja i Južna Amerika. U Europi smrtnu kaznu zadržava još samo Bjelorusija (koja je i izvršava), a u Srednjoj i Južnoj Americi formalno su je zadržale samo Belize i Gvajana (premda su obje de facto abolicionističke).

o Što se europskih međunarodnih organizacija i asocijacija tiče, ukidanje smrtne kazne pretpostavka je za članstvo u Europskoj uniji. Borba za ukidanje smrtne kazne u svijetu jedan je od vanjskopolitičkih prioriteta EU-a i prigodom dijaloga s trećim državama predstavnici EU-a redovito u kontekstu zaštite ljudskih prava pokreću i pitanje napuštanja smrtne kazne.

o Za članstvo u Vijeću Europe preduvjet je da država članica ne izvršava smrtnu kaznu. To je zanimljivo i zato što je Europska konvencija o ljudskim pravima izričito predvidjela smrtnu kaznu kao iznimku u odnosu na pravo na život. Međutim, široko prihvaćanje Protokola 6. iz 1985. na Konvenciju kojim se smrtna kazna ukida u mirnodopskim uvjetima, te Protokola 13. iz 2003. kojim se smrtna kazna ukida u svim uvjetima, dovelo je do promjena u tome kako Europski sud za ljudska prava tumači Konvenciju. ${ }^{85}$ Evolucija se odvijala kroz odluke oko (ne) izručenja osoba onim državama koje još zadržavaju smrtnu kaznu. Dok su ranije odluke o neizručenju sadržavale specifične razloge, primjerice da bi duljina čekanja na izvršenje ${ }^{86}$ ili način izvršenja mogli predstavljati mučenje ${ }^{87}$, odnosno nehumanu ili ponižavajuću kaznu, odluka u slučaju Al-Sadoon i Mufdhi protiv Ujedinjenog Kraljevstva ne navodi nikakve specifične razloge osim prijetnje pogubljenjem, navodeći da bi ono bilo suprotno Konvenciji, za koju se nakon širokog prihvaćanja dodatnih protokola o njezinu ukidanju može smatrati da je izmijenjena tako da zabranjuje smrtnu kaznu. ${ }^{88}$

o Značajnu ulogu u ukidanju smrtne kazne u Africi mogao bi imati Afrički sud za ljudska prava i prava naroda. Povelja Afričke unije sadržava odredbe o pravu na život i pravu na dostojanstvo te ne predviđa smrtnu kaznu kao iznimku. Ako se pojavi odgovarajući slučaj pred

85 Od 47 članica Vijeća Europe 46 je ratificiralo Protokol 6. (sve osim Rusije), a 44 Protokol 13. (sve osim Rusije, Armenije i Azerbajdžana).

86 Vidi, primjerice, Soering protiv Ujedinjenog Kraljevstva iz 1989. Sud se protivi izručenju u SAD jer duljina čekanja na izvršenje smrtne kazne, uvjeti pri tome i učinci na psihu osuđenika predstavljaju mučenje.

87 Vidi Jabari protiv Turske iz 2000. Sud se protivio izručenju u Iran jer bi mogućnost pogubljenja kamenovanjem predstavljala mučenje.

88 Vidi Al-Saadoon and Mufdhi v. United Kingdom (no. 61498/08), posebno para 120. 
Sudom, on bi mogao ocijeniti da smrtna kazna vrijeđa pravo na život i dostojanstvo (ili dostojanstveni život) predviđene Poveljom te da stoga predstavlja njezino kršenje. ${ }^{89}$ Afrička komisija za ljudska prava i prava naroda već je usvojila tri rezolucije (1999., 2008. i 2017. godine) kojima poziva države stranke Afričke povelje o ljudskim pravima i pravima naroda da se drže moratorija na smrtnu kaznu. ${ }^{90}$

o Od 35 država članica Organizacije američkih država 25 ih je ratificiralo Američku konvenciju o ljudskim pravima koja obvezuje države koje su ukinule smrtnu kaznu da je ponovno ne uvode. Dok su Srednja i Južna Amerika gotovo potpuno napustile smrtnu kaznu, SAD i Karibi, premda su i oni na putu odmicanja od smrtne kazne, još nisu. ${ }^{91}$

o Najveći su izazovi u napuštanju smrtne kazne još pred nekim muslimanskim državama i Azijom, osobito Kinom. Kod muslimanskih država ključno bi bilo da prevladaju vjerske interpretacije koje se protive pogubljenjima zbog mogućnosti pravosudnih pogrešaka i stradanja nevinih. Baš kao što je, premda Biblija predviđa smrtnu kaznu, cjelovito tumačenje njezinih protuslovnih odredbi napokon dovelo do promjene Katekizma u smislu protivljenja smrtnoj kazni, nešto slično, premda manje centralizirano, moglo bi biti moguće i u pogledu tumačenja Kurana.

o U pogledu Azije, posebno je važno da se Kina, u kojoj se još uvijek pogubljuje uvjerljivo najviše, nastavi odmicati od smrtne kazne. Broj kaznenih dijela za koje se može izreći smrtna kazna posljednjih godina već je znatno smanjen, a uvedeni su i dodatni kontrolni mehanizmi prije izvršenja kazne. Premda su kineske vlasti već donijele stratešku odluku o postupnom napuštanju smrtne kazne, vjerojatno je da će taj proces biti vrlo postupan i ovisiti o širem kontekstu odnosa spram ljudskih prava te autoritarnosti ili demokracije.

89 Takav sam dojam stekao na sastanku sa sucima Afričkog suda za ljudska prava i prava naroda u sjedištu Suda u Addis Abebi 2018. godine. Pokazali su velik interes za evoluciju u judikaturi Europskog suda za ljudska prava, koju sam već spomenuo. Kod Afričkog suda to bi moglo ići i brže jer Povelja Afričke unije ne spominje smrtnu kaznu kao izuzetak u odnosu na pravo na život, kao Europska povelja.

Afrička komisija inicirala je (po uzoru na proces u Vijeću Europe i mijenjanje Europske konvencije o ljudskim pravima Protokolima 6. i 13.), donošenje Protokola o ukidanju smrtne kazne u Africi. Mislim da bi takav Protokol i njegova postupna ratifikacija otežala Sudu donošenje odluke o protivnosti smrtne kazne Povelji Afričke unije, o čemu sam razgovarao s Komisijom i Sudom.

91 Guverner države Colorado potpisao je zakon o ukidanju smrtne kazne 23. ožujka 2020., čime je broj država u SAD-u koje su ukinule smrtnu kaznu porastao na 22. 


\subsection{Ključni čimbenici}

Iskustvo je pokazalo da su za napuštanje smrtne kazne relevantni mnogi čimbenici, ali posebno je važan stupanj obaviještenost o smrtnoj kazni te uloga vodstva.

- Činjenice o smrtnoj kazni, empirijska istraživanja i objavljivanje njihovih rezultata u raznim su dijelovima svijeta djelovali na njezino napuštanje. U pravilu, što ljudi više znaju o smrtnoj kazni, to je manje podupiru. ${ }^{92}$ Statistički podaci, ali i konkretne životne priče o nevino osuđenima, žrtvama diskriminacije, nepostojanju dokaza o odvraćajućim učincima smrtne kazne, užasnim mukama tijekom pogubljenja te tragičnim iskustvima kako smrtna kazna pogađa nevine treće osobe, utjecale su ne samo da se pojedinci okrenu protiv smrtne kazne, već i čitave države.

Hipotezu o tome da što više ljudi znaju o smrtnoj kazni, to je manje podupiru, testirao sam školske godine 2018./2019. na studentima prve godine Pravnog fakulteta Sveučilišta u Zagrebu, seminaristima Opće teorije prava (osam grupa, 183 studenata). Stav studenata prema smrtnoj kazni ispitivao sam prije i poslije dvosatnog predavanja tijekom kojeg su bili upoznati s činjenicama $i$ istraživanjima u pogledu smrtne kazne i njezinih učinaka. Izjašnjavanje prije predavanja već je pokazalo je da još samo mali broj studenata podupire smrtnu kaznu (29, odnosno 16 posto za, 127 odnosno 69 posto protiv te 15, odnosno 27 posto suzdržanih). ${ }^{93}$ Studenti su poslije dvosatnog predavanja ponovno pozvani da se izjasne jesu li za smrtnu kaznu, protiv ili suzdržani. ${ }^{94}$ Od osam grupa, u čak sedam je podrška smrtnoj kazni nakon predavanja pala, a u samo jednoj rezultati su ostali nepromijenjeni. Ukupno gledano, za smrtnu kaznu nakon predavanja izjasnilo se 21 , odnosno 11 posto studenata, protiv 148, odnosno 81 posto, dok je 14, odnosno 8 posto bilo suzdržano. Hipoteza o tome da što više ispitanici znaju o smrtnoj kazni, to je manje podupiru tako je na uzorku studenata Pravnog fakulteta uvjerliivo potvrđena.

- Premda se povijesno i globalno gledano stav javnog mnijenja u odnosu na smrtnu kaznu postupno mijenja u prilog njezina napuštanja, u golemoj

92 Za istraživanje o utjecaju informiranosti na odnos spram smrtne kazne vidi Sato, M., The Death Penalty in Japan: Will the Public Tolerate Abolition?, Springer, Berlin, 2014., str. 127 - 156. Također, Haney, C., Death by Design: Capital Punishment as a Social Psychological System, Oxford University Press, New York, 2005.

Istraživanje je provedeno između 3. rujna 2018. i 8. siječnja 2019.

Da izbjegnem da na njihovo odlučivanje utječe moj osobni stav, već prije prvog izjašnjavanja obznanio sam da sam abolicionist, ali i da poštujem i zanima me njihov stav, ma kakav on bio. Promjenu stava moglo se, dakle, pripisati novim informacijama o smrtnoj kazni i njezinim posljedicama. 
većini država smrtna se kazna napuštala dok ju je većina još podržavala. Iskustvo je također pokazalo da u pravilu većina populacije postaje protivnicima smrtne kazne tek mnogo godina nakon njezina napuštanja. ${ }^{95}$ Kako, što se javnog mnijenja tiče, "abolicija stvara abolicioniste", uloga vodstva koje je spremno preuzeti inicijativu i odgovornost vrlo je bitna za napuštanje smrtne kazne.

U inicijative za napuštanje smrtne kazne s pozicija državnog vodstva ${ }^{96}$ najčešće su se upuštali poglavari država ili vlada, parlamentarci ili pravosudni autoriteti. ${ }^{97}$ Oni su u prednosti u odnosu na opću populaciju po tome što su im u pravilu bolje poznate činjenice o smrtnoj kazni, ali, ako se zalažu za napuštanje smrtne kazne protiv većinskog javnog mnijenja, izlažu se političkim rizicima koje njihovi suparnici mogu iskoristiti u borbi za vlast.

U većini (posebice razvijenih) država koje još uvijek zadržavaju smrtnu kaznu vodstvo se sve manje poziva na argumente za i protiv smrtne kazne zasnovane na činjenicama i rezultatima istraživanja, a sve više na demokraciju i volju većine, navodeći kako bi napuštanje smrtne kazne dok je većina još podržava podrovalo pravosudni sustav i povjerenje u njega..$^{98} \mathrm{To}$ djeluje donekle uvjerljivo samo tako dugo dok se ne zagrebe ispod površine formalnog izjašnjavanja populacije za i protiv smrtne kazne. Istraživanja Mai Sato pokazala su tako da stav znatne većine u Japanu protiv smrtne kazne, kakav su odražavala vladina istraživanja, niti je tako čvrst, niti nepromjenljiv kako se to prikazivalo. Serijom drukčije postavljenih pitanja Sato je pokazala da znatna većina u Japanu jest za zadržavanje smrtne kazne, ali da bi prihvatila i njezinu aboliciju ako je takav stav stručnjaka i nadležnih organa. ${ }^{99}$ Tako bi čak 71 posto podržavatelja smrtne kazne prihvatilo i njezino ukidanje ako tako odluči Vlada. ${ }^{100}$

Kakvo će onda vodstvo biti najsklonije napuštanju smrtne kazne? Kako smo već spomenuli, autoritarni režimi, gdje je uloga većinskog javnog

95 Hoyle, C.; Hood, R. Deterrence and public opinion, u: Sato, Bacon, op. cit. u bilj. 42, str. $80-81$.

96 Ne treba zanemariti ni veliku ulogu civilnog društva, posebice pravne struke i udruga za ljudska prava koje spominjemo drugdje.

97 Vidi Sato, M., Vox populi, vox dei, u: Šimonović, op. cit. u bilj. 15, str. 258 i opširnu citiranu literaturu.

98 Vidi Šimonović, I., Foreword, u: Sato, Bacon, op. cit. u bilj. 42, str. 9.

99 Vidi Sato, op. cit. u bilj. 92, i Sato, Bacon, op. cit. u bilj. 42.

100 Sato, Bacon, op. cit. u bilj. 42, str. 12. 
mnijenja manje bitna, skloniji su smrtnoj kazni. U demokratskim državama, vodstva ponajprije usredotočena na zadržavanje svojeg položaja, prikazuju da smrtnu kaznu zadržavaju zbog volje većine. Do odmicanja od smrtne kazne stoga će u pravilu dolaziti u onim demokratski orijentiranim državama u kojima će se vodstvo biti spremno zauzeti za odmicanje od smrtne kazne iz principijelnih razloga, prihvaćajući trenutačne političke rizike koje to nosi za njih osobno. ${ }^{101} \mathrm{U}$ shvaćanju demokracije pritom se ravnaju ne prema mehaničkom zakonu brojeva (što može voditi i diktaturi većine), nego razlozima zaštite humanosti i ljudskih prava te vjerom $u$ mogućnost pozitivne evolucije ljudskog društva.

Neki budući reformatori na pozicije vodstva već dolaze s uobličenim stavom $u$ prilog napuštanja smrtne kazne, dok se kod drugih takav odnos postupno razvija pod utjecajem dodatnih informacija o smrtnoj kazni i njezinim učincima. Dobar primjer za mogućnost evolucije osobnog stava spram smrtne kazne je slučaj bivšeg glavnog tajnika UN-a Ban Ki-moona. U početku Ban nije djelovao kao netko tko će se razviti u šampiona abolicionizma, dapače. Kada je kao donedavni ministar vanjskih poslova Republike Koreje došao u New York da preuzme položaj glavnog tajnika, novinari su ga odmah zaskočili pitanjem o smrtnoj kazni nad Sadamom Huseinom. Tada je njegov komentar bio da je izricanje i izvršavanje smrtne kazne suvereno pravo svake države. Tijekom godina Ban se prometnuo ne samo u podržavatelja napuštanja smrtne kazne, nego i aktivnog zagovaratelja njezine abolicije. ${ }^{102}$ U predgovoru prvoj knjizi o smrtnoj kazni koju sam uredio za UN naveo je kako smrtnoj kazni nema mjesta u 21. stoljeću i pozvao vodeće dužnosnike širom svijeta da se založe za njezino napuštanje. ${ }^{103} U$ predgovoru

101 Neki takav rizik jednostavno ne žele prihvatiti. Predsjednik države koja zadržava smrtnu kaznu premda je svuda u široj regiji ukinuta rekao mi je neuvijeno da on ne vjeruje da smrtna kazna djeluje odvraćajući, ali njegovi birači vjeruju da djeluje. Ako se založi za ukidanje, a ionako visoka stopa najtežih djela naraste, platio bi za to političku cijenu i vjerojatno izgubio sljedeće izbore. Zato podržava da se u njegovoj zemlji odvija kampanja za napuštanje smrtne kazne i cijeni međunarodnu pomoć $u$ tome, ali nije spreman prije promjene javnog mnijenja poduzeti daljnje korake.

102 Ban je tako aktivno sudjelovao u nizu panela posvećenih napuštanju smrtne kazne koje sam vodio pri UN-u u New Yorku. To je, među ostalim, bila prilika da se osobno upozna s nevino osuđenima na smrt, žrtvama diskriminacije u primjeni smrtne kazne, stručnjacima čija su istraživanja jasno pokazala da nema dokaza da smrtna kazna odvraća zločine, obiteljima žrtava koje su odbijale smrtnu kaznu za počinitelje te nevinim trećim osobama koje su bile duboko pogođene smrtnom kaznom. Njegovo zalaganje za napuštanje smrtne kazne kroz vrijeme je postajalo sve snažnije. Danas se zalaže za aboliciju smrtne kazne u Republici Koreji.

103 Vidi Šimonović, op. cit. u bilj. 15, str. 7. 
druge naveo je da je pravo na život izvor svih drugih ljudskih prava te pozvao državne vođe, parlamentarce i pravosudne dužnosnike da se založe za trenutačni prekid svih egzekucija. ${ }^{104}$

Dobar primjer postupne institucionalne evolucije na dulji rok, nakon koje slijedi odlučni pojedinačni iskorak, odnos je Katoličke crkve spram smrtne kazne. Nakon što su se već i neki raniji pape, posebno od Drugog vatikanskog koncila, sve više ograđivali od smrtne kazne i pozivali na njezino napuštanje, smiona odluka pape Franje da promijeni Katekizam Katoličke crkve i proglasi smrtnu kaznu suprotnom njezinu učenju, "jer predstavlja napad na osobnu nepovredivost $i$ dostojanstvo", te da se stoga Katolička crkva treba odlučno zalagati za njezino napuštanje, vjerojatno će imati dalekosežne učinke. ${ }^{105}$

\section{ZAKLJUČAK}

U ovom članku pokušao sam prikazati kako se rezultati novijih istraživanja odražavaju na klasične argumente protiv smrtne kazne i za smrtnu kaznu te upozoriti na neke nove argumente na koje upućuju. Nije riječ samo o gomilanju dodatnih dokaza: mislim da je rasprava o smrtnoj kazni promijenila kvalitetu.

Generacijama studenata i sudionicima na tribinama o smrtnoj kazni širom svijeta naglašavao sam da je abolicionizam moje čvrsto uvjerenje, ali da poštujem i druge stavove te da sam spreman s njima polemizirati. Više nisam siguran da je sasvim tako.

Razvoj shvaćanja o ljudskim pravima sve više dovodi u pitanje legitimnost smrtne kazne. Povijesno, prag različitih relevantnih ljudskih prava koja svima moraju biti zajamčena postupno se povisivao. Sazrijeva shvaćanje da smrtna kazna jednostavno nije moguća, a da se ne povrijede neka ljudska prava: u prvom redu pravo na život, ali i na zaštitu od okrutnog, nehumanog ili ponižavajućeg postupanja, što je s aspekta ljudskih prava čini nelegitimnom. ${ }^{106}$ Takvo shvaćanje

104 Ibid.

105 Vidi reviziju 2267 Katekizma Katoličke crkve o smrtnoj kazni od 02. 08. 2018. Razgovori koje smo nekoliko kolega iz Međunarodnog povjerenstva protiv smrtne kazne i ja tim povodom vodili s papom Franjom i državnim tajnikom Svete Stolice, uključivali su i temu kako ovaj veliki potencijal praktično iskoristiti za borbu protiv smrtne kazne.

106 To neke autore navodi na zaključak da se promijenio normativni odnos spram smrtne kazne. Dok je prije smrtna kazna bila norma, sad je to abolicija. Teret dokaza da opravdaju svoju poziciju prelazi na one države koje zadržavaju smrtnu kaznu (vidi Heynes, Probert, op. cit. u bilj. 29, str. 218). 
se iz Europe i Latinske Amerike, gdje već prevladava, postupno širi i drugdje po svijetu. Slikovito rečeno, po mojem sudu međunarodno pravo o ljudskim pravima i na njima zasnovani društveni ugovor između pojedinaca i države u 21. stoljeću ne bi više smjeli uključivati smrtnu kaznu.

Još uvijek se godišnje pogubljuju tisuće ljudi, premda je sve jasnije da smrtna kazna ne odvraća najteže zločine, niti većini obitelji žrtava donosi utjehu. Među onima koji su na nju osuđeni, žrtvama smrtne kazne u najmanju ruku možemo smatrati nevino osuđene te sve one kojima su prilikom odlučivanja o smrtnoj presudi ili njezinim izvršenjem povrijeđena neka ljudska prava. U krug žrtava smrtne kazne svakako treba ubrojiti i nevine treće osobe koje su ovom kaznom pogođene mnogo snažnije nego bilo kojom drugom. Među njih treba uključiti ne samo obitelji i druge bliske s osuđenikom, već i sudionike u postupku izricanja i izvršenja smrtne kazne. Svi oni često trpe ozbiljne psihološke posljedice izazvane smrtnom kaznom.

No, smrtnom kaznom nisu pogođeni samo pojedinci, već i čitave grupe, pa i društvo u cjelini.

Podaci nesumnjivo pokazuju da je smrtna kazna u pravilu diskriminatorna u svojoj primjeni te da neproporcionalno često pogađa pripadnike najranjivijih društvenih skupina (manjine, migrante, siromašne) te da stoga odstupa od načela jednakosti svih pred zakonom. Uz to, smrtna kazna negativno utječe na društvo u cjelini te na odnos između države i pojedinca. Smrtna kazna simbol je društvenog ustroja u kojem je u središtu državna moć, a ne pojedinac i njegova prava. I upravo kada smo došli na sam rub delegitimiziranja takvog ustroja, svijet je zahvatio kovitlac koji dosadašnja postignuća dovodi u pitanje.

I nacionalno, i regionalno, i globalno postoje prijelomna razdoblja kada društveni trendovi mogu promijeniti smjer i kada je budućnost otvorena. Nalazimo se u takvom razdoblju. Odnos spram smrtne kazne samo je dio takvog šireg sklopa mogućih negativnih promjena. Nakon dužeg razdoblja sustavnog napredovanja, posljednjih godina demokracija i ljudska prava, kao okružje koje je pomagalo proces napuštanja smrtne kazne, nazaduju. Kao rezultat neuspješnog upravljanja globalizacijskim procesima, i u razvijenim državama, i u državama u razvoju, nezadovoljstvo raste i jačaju autoritarne tendencije. Pandemija COVID-19 i njezino razbuktavanje 2020. godine, te iskorištavanje potrebe da se učinkovito odgovori na zdravstvene prijetnje te gospodarske i društvene posljedice od strane nekih režima da bi se preko potrebne mjere suzile demokratske slobode i zaštita ljudskih prava, dodatno su negativno utjecali. Sve spomenuto pogotovo je važno i osjetljivo u uvjetima kada se gospodarska, politička i vojna moć postupno sa zapada sele na istok i jug, gdje su i autoritarnost i sklonost smrtnoj kazni jači. To se za sada još nije odrazilo na numeričke indikatore procesa napuštanja smrtne 


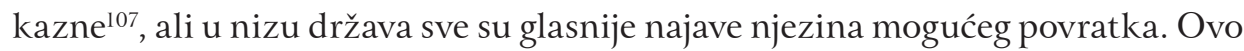
je trenutak kada treba uložiti dodatne napore da se to zaustavi.

Pravo države da oduzima život uklapa se u autoritarnu paradigmu. Borba protiv smrtne kazne stoga dodatno dobiva na važnosti u uvjetima kada globalno pada podrška demokraciji i ljudskim pravima, a jača autoritarnost. I to ne samo zato što se porast autoritarnosti odražava na jačanje podrške smrtnoj kazni, nego se smrtna kazna pretvara u simbol borbe za jačanje ili protiv jačanja autoritarnosti. Borba protiv smrtne kazne u ovom razdoblju stoga je i borba za karakter društava i pravnih sustava u kojima živimo i njihovu budućnost: želimo li u središtu državnu moć ili ljudska prava?

Kako se u ovom prijelomnom trenutku najučinkovitije boriti protiv smrtne kazne? Ponegdje će umijeće biti držati zauzete pozicije, a drugdje pokušati nastaviti napredak u napuštanju smrtne kazne. Pri tome, zalaganje za aboliciju odmah ili postupnost u smislu zalaganja za moratorij ili čak sužavanje primjene smrtne kazne taktičko je pitanje i pragmatični kompromisi moralno su prihvatljivi ako je abolicija postavljena kao konačni cilj, makar u budućnosti.

Da bi se spriječio globalni povratak smrtne kazne i nastavilo njezino napuštanje, potreban je napor širokog kruga aktera. Pri tome na nacionalnom planu posebno važnu ulogu imaju visoki državni i pravosudni dužnosnici, neovisne institucije za zaštitu ljudskih prava, civilno društvo općenito te posebno akademske institucije i pravna struka kao čuvari i potencijalni promicatelji znanja o smrtnoj kazni i njezinim štetnim učincima.

Visoki nacionalni dužnosnici mogu u pogledu smrtne kazne imati i pozitivnu i negativnu ulogu. U slučaju da autoritarni i populistički lideri u zemljama koje su je već napustile pokušaju ponovno uvesti smrtnu kaznu, upravo bi pravni fakulteti i pravna znanost kroz rigorozan akademski, na činjenicama i ljudskim pravima zasnovan pristup ovom pitanju, trebali imati ključnu odvraćajuću ulogu. U zemljama pak koje još zadržavaju smrtnu kaznu, njihova je zadaća da kroz istraživanja, širenje znanja i informiranje o učincima smrtne kazne stalno pojačavaju pritisak s ciljem njezina napuštanja.

Premda je do relativno nedavno globalno kretanje u smjeru demokracije i ljudskih prava te napuštanja smrtne kazne izgledalo kao zavojita, ali jednosmjerna ulica, danas više nije tako. Hoćemo li uspjeti prevladati izazove u pogledu povratka autoritarnosti i smrtne kazne? Ne znam, ali sasvim je jasno da što se

107 Dobar indikator mijenja li se trend biti će rezultat glasovanja za Rezoluciju Opće skupštine UN-a o moratoriju na izvršenje smrtne kazne sa svrhom njezina postupnog ukidanja koje će se održati u prosincu 2020. u New Yorku, ako to budu dozvoljavali epidemiološki uvjeti. 
više trudimo, to su šanse veće. Borba protiv smrtne kazne važan je dio šireg mozaika borbe za zaštitu ljudskih prava svakog pojedinca te za karakter društava u kojima će živjeti naše potomstvo.

\section{LITERATURA}

\section{Knjige}

Acker, J. R.; Lanier, C. S. (ur.), America's Experiment with Capital Punishment: Reflections on the Past, Present, and Future of the Ultimate Penal Sanction, trecee izdanje, NC: Carolina Academic Press, Durham, 2014.

Garrett, B. L., Convincting the Innocent, Harvard University Press, Cambridge Massachusetts, London England, 2011.

Gerber; R. J.; Johnson, J. M., The Top 10 Death Penalty Myths, Praeger, Westport, Connecticut, 2007.

Haney, C., Death by Design: Capital Punishment as a Social Psychological System, Oxford University Press, New York, 2005.

Hoyle, C.; Hood, R., The Death Penalty: A Worldwide Perspective, peto izdanje, Oxford University Press, Oxford, 2015.

Hood, R., The Death Penalty - A Worldwide Perspective, Clarendon Press, Oxford, 1996.

King, R., Don't Kill in Our Names, Rutgers University Press, New Bruswick, New Jersey, 2003.

Sarat, A., Gruesome Spectacles: Botched Executions and America's Death Penalty, Stanford University Press, Stanford, 2014.

Sato, M., The Death Penalty in Japan: Will the Public Tolerate Abolition?, Springer, Berlin, 2014.

Stevenson, B., Just Mercy, Spiegel \& Grau, New York, 2014.

Sharp, S. F., Hidden Victims: The Effects of the Death Penalty on Families of the Accused, Rutgers University Press, New Brunswick, 2005.

Šimonović, I. (ur.), Moving Away from the Death Penalty: Arguments, Trends and Perspectives, United Nations, New York, 2015.

Šimonović, I. (ur.), Death penalty and victims, United Nations, New York, 2016.

\section{2. Časopisi}

Muller, R., Death Penalty May Not Bring Peace to Victims' Families, Psychology Today, October 19, 2016. 
Phillips, S.; Marceau, J., Whom the State Kills, Phillips, Harvard Civil Rights - Civil Liberties Law Review, izlazi 2020, U Denver Legal Studies Research Paper No. 19-16, raspoloživo na SSRN: https://ssrn.com/abstract=3440828 or http:// dx.doi.org/10.2139/ssrn.3440828.

Radelet, M., The Incremental Retributive Impact of a Death Sentence Over Life Without Parole, University of Michigan Journal of Law Reform, sv. 49, br. 4, 2016., str. $795-815$.

Radelet, M.; Lacock, T. L., Do Executions Lower Homicide Rates: The Views of Leading Criminologists', The Journal of Criminal Law and Criminology, sv. 99, br. 2, 2009., str. $489-507$.

Zimmering, F.; Fagan, D. J.; Johnson, T., Executions, deterrence and homicide: A tale of two cities, Journal of Empirical Legal Studies, sv. 7, br. 1, 2010., str. 1 - 29.

\section{Izvješća}

Amnesty International global report: Death sentences and executions 2019, Amnesty international 2020.

Amnesty International global report: Death sentences and executions 2018, Amnesty international 2019.

Gross, S. R.; O’Brien, B.; Hu, C.; Kennedy E. H., Rate of false conviction of criminal defendents who are sentenced to death, Proceedings of the National Academy of Sciences of the United States of America, sv. 111, br. 20, 20. svibnja 2014., str. $7230-7235$.

Deterrence and the Death Penalty, National Research Council of the National Academies, National Academic Press, Washington DC, 2012.

Deterrence and Incapacitation: Estimating the Effects of Criminal Sanctions on Crime Rates, National Academy of Sciences, Washington, 1978.

Fagan, J., An exemination of the Death Penalty in the United States: Hearing Before the Subcommittee on the Constitution, Civil Rights and Property Rights of the Senate Committee on the Judiciary, 109th Cong., 2d Sess. 21-35 (2006).

Freedom in the World 2018 report, the Annual Survey of Political Rights and Civil Liberties, Freedomhouse, New York and Washington, 2019.

How States Abolish the Death Penalty: 29 Case-Studies, International Commission Against Death Penalty, Madrid, 2018.

Sato, M.; Bacon, P., The Public Opinion Myth: Why Japan retains the death penalty, The Death Penalty Project, London, 2015. 


\section{Dokumenti}

European Convention for the Protection of Human Rights and Fundamental Freedoms, Rim, 4. studeni 1950.

General Assembly resolution 2857 (XXVI), Capital punishment, A/RES/2857 (20. prosinac 1971.).

General Assembly resolution 73/175, Moratorium on the use of the death penalty, A/RES/73/175 (17. prosinac 2018.).

International Covenant on Civil and Political Rights, New York, 16 December 1966 (Pakt je usvojen rezolucijom Opće skupštine UN 2200A (XXI) od 16. prosinca 1966.).

Universal Declaration of Human Rights, 10 December 1948 (Usvojena rezolucijom Opće skupštine UN 217 A(III) od 10. prosinca 1948.).

\section{Sudska praksa}

Al-Saadoon and Mufdhi v. United Kingdom, European Court of Human Rights (no. 61498/08).

Kansas v. Marsh, 548 U.S. 163, 194-195 (2006) (Scalia, J. concurring).

Furman v. Georgia, 408 US 238 (Supreme Court 1972). No. 69-5003, Argued January 17, 1972. Decided June 29, 1972.

Gregg v. Georgia, 428 US 153 (Supreme Court 1976) No. 74-6257. Argued March 31, 1976. Decided July 2, 1976. 


\section{Summary}

\section{Ivan Šimonović*}

\section{WHY FIGHT AGAINST THE DEATH PENALTY MATTERS?}

Evidence clearly indicates that there is a long-term trend of moving away from the death penalty. Although the death penalty is still not forbidden by the international law, the international legal framework increasingly obliges states to keep on moving away from it. However, current trends of strengthening of authoritarianism and weakening of human rights threaten to put in danger these achievements.

The results of recent empirical researches strengthen traditional arguments against the death penalty: wrongful convictions do occur in practice, arbitrariness and discrimination in its implementation are widespread, and it is (almost) impossible to execute a person without violating some human rights. In the same time, they weaken the arguments traditionally used in favour of retention: not all families of victims want such a revenge (and the ones who want it, mostly end up frustrated) and there is no reliable evidence that the death penalty deters crime.

In addition, they point to some new arguments against the death penalty. When compared to other forms of punishment, the death penalty disproportionally affects the mental health and well-being of innocent third persons: family members of those convicted, as well as participants of criminal proceedings or executions, such as prosecutors, judges, lawyers and prison staff. It also affects society as whole. Author's brief, evidence based comparison between countries' level of democracy and their attitude towards the death penalty, clearly demonstrates high correlation between the death penalty and authoritarianism.

Experience shows that information and the role of leadership are critical factors for moving away from the death penalty. The more information on the death penalty, the less people support it (a test involving Zagreb law school students confirmed this hypothesis). Leaders who are democratically oriented and whose politics is value based, are the most likely to support moving away from the death penalty. Fight against the death penalty is important for promotion and protection of human rights of every individual, as well as for the democratic future of our societies.

Keywords: death penalty; human rights; sovereignty; authoritarianism; victims

* Ivan Šimonović, Ph. D., Professor, Faculty of Law, University of Zagreb, Trg Republike Hrvatske 14, 10000 Zagreb, Croatia; Ambassador, Permanent Representative, Permanent Mission of the Republic of Croatia to the United Nations, 820 Second Avenue, 19th Fl., New York, N.Y. 10017, U. S. A.; ivan.simonovic@mvep.hr; ORCID ID: orcid.org/0000-0003-2209-8953 